Prace Historyczno-Archiwalne t. XXXIII, Rzeszów 2021

ISSN: 1231-3335

\author{
Ewa Koper \\ ORCID 0000-0003-3610-367X \\ DOI:10.30657/pha.33.2021.15 \\ (Muzeum i Miejsce Pamięci w Bełżcu, \\ Oddział Państwowego Muzeum na Majdanku) \\ e-mail: ewakoper01@gmail.com
}

\title{
Rotunda - pierwsze upamiętnione miejsce martyrologii na Zamojszczyźnie
}

\section{Streszczenie}

Rotunda była obiektem o charakterze militarnym w systemie obronnym Twierdzy Zamość w XIX wieku. Podczas II wojny światowej pełniła rolę jenieckiego obozu przejściowego niemieckiej Policji Bezpieczeństwa. W latach 1940-1944 zginęło tam wielu przedstawicieli lokalnych elit i członków konspiracji. Liczba szacunkowa ofiar wynosi około ośmiu tysięcy. Najprawdopodobniej przez obóz przeszło 50 tys. więźniów. Po wojnie było to pierwsze miejsce upamiętnione w regionie. Inicjatywa upamiętnienia była rezultatem działań społecznych. Pomimo różnych problemów, udało się zabezpieczyć obiekt wraz z przyległym terenem. W latach 50. XX w. ekshumowano na Rotundę wiele ciał ofiar II wojny światowej. Obecnie stanowi ona bardzo ważny symbol martyrologii na Zamojszczyźnie. Pochowano tam m.in. żołnierzy polskich, którzy polegli we wrześniu 1939 roku, partyzantów, ludność żydowską i romską oraz żołnierzy sowieckich.

\section{Słowa kluczowe:}

II wojna światowa, martyrologia, miejsce pamięci, Zamojszczyzna.

$G$ efangenen Durchgangslager Sicherheitspol. - jeniecki obóz przejściowy niemieckiej Policji Bezpieczeństwa funkcjonował w latach 1940-1944 w Zamościu. Jego uruchomienie wiązało się początkowo z akcją $A B$, prowadzoną przez Niemców w Generalnym Gubernatorstwie od maja do lipca 1940 r., a następnie z eksterminacją członków konspiracji ${ }^{1}$. Po wojnie szacowano liczbę zamordowanych na około 20 tys. osób ${ }^{2}$. Obecnie przyjmuje się liczbę około 8 tys. ofiar ${ }^{3}$. Przypuszczalnie przez obóz przeszło 50 tys. więźniów. W wyniku powojennych ekshumacji poległych

Zob. http://muzeum-zamojskie.pl/418, dostęp 17 IV 2019.

2 Archiwum Państwowe w Zamościu [dalej: APZ], Starostwo Powiatowe w Zamościu, sygn. 876, k. 7.

3 Trudności w ustaleniu liczby ofiar wynikały z faktu, że wiele ciał zostało spalonych. 
i zamordowanych z terenu Zamojszczyzny przyjęto, że spoczywają tam szczątki 45482 ofiar, głównie narodowości polskiej, ale też rosyjskiej i żydowskiej ${ }^{4}$.

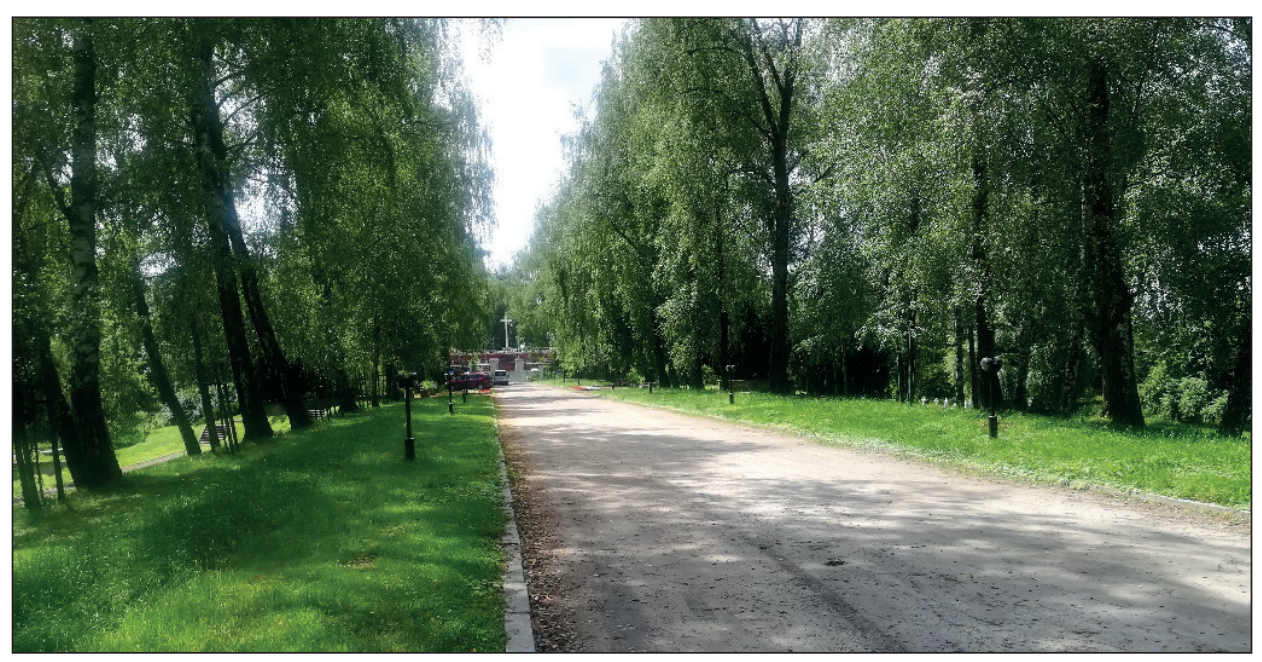

Fot. 1. Aleja główna na Rotundzie w Zamościu (fot. Ewa Koper, Zamość, 8 lipca 2020 r.).

Po zakończeniu II wojny światowej ważną rolę w dokumentowaniu zbrodni popełnionych na Zamojszczyźnie odegrał społeczny Komitet Budowy Pomnika Mauzoleum „Rotunda” (KBPM „Rotunda”). Komitet powołano w Zamościu już w sierpniu 1944 r. Na pierwszego przewodniczącego wybrano Stefana Milera, następnie Jana Ogórkiewicza $^{5}$. Nadrzędnym zadaniem Komitetu stało się upamiętnianie ofiar i zabezpieczenie miejsca kaźni podległego Gestapo. Wśród działań, które prowadzono do 1949 r., znalazła się również współpraca z Sądem Grodzkim w Zamościu oraz Międzynarodowym Trybunałem w Norymberdze ${ }^{6}$.

Zgodnie z założeniami, Rotunda miała pełnić rolę szczególną. Podkreślono ogromną wagę tworzenia cmentarza wojennego o charakterze pomnika, z myślą o wszystkich poległych i zamordowanych. Uważano, że „cmentarz na Rotundzie będzie wiecznym dokumentem zbrodni niemieckich, a zarazem przedmiotem czci całego społeczeństwa”7 . Na początku sierpnia 1945 r. podobnie pisał Stefan Miler: „(...) powstała spontaniczna myśl uczczenia bohaterów, którzy zginęli za polskość, oraz uświęcenia tego miejsca, będącego relikwią całej Zamojszczyzny"8. Zaangażowanie społeczne przyczyniło się wydatnie do ukształtowania powojennej funkcji tego miejsca.

4 Zob. http://www.zamosciopedia.pl/index.php/ro-rr/item/3195-rotunda-oboz-hitlerowski, dostęp 17 IV 2019.

5 Zob. http://muzeum-zamojskie.pl/wp-content/uploads/2016/04/BIBLIOTEKA-ROTUNDA.pdf, dostęp 13 V 2018.

6 Ibidem.

7 APZ, Starostwo Powiatowe w Tomaszowie Lubelskim, sygn. 785, k. 6, 7.

8 Archiwum Państwowe w Lublinie [dalej: APL], Urząd Wojewódzki Lubelski, Wydział Odbudowy, Oddz. I, Ref. Gr.W I/1945/46/47 r., Sprawy ewidencji i opieki nad grobami wojennymi, Zamość, sygn. 227, k. 25. 


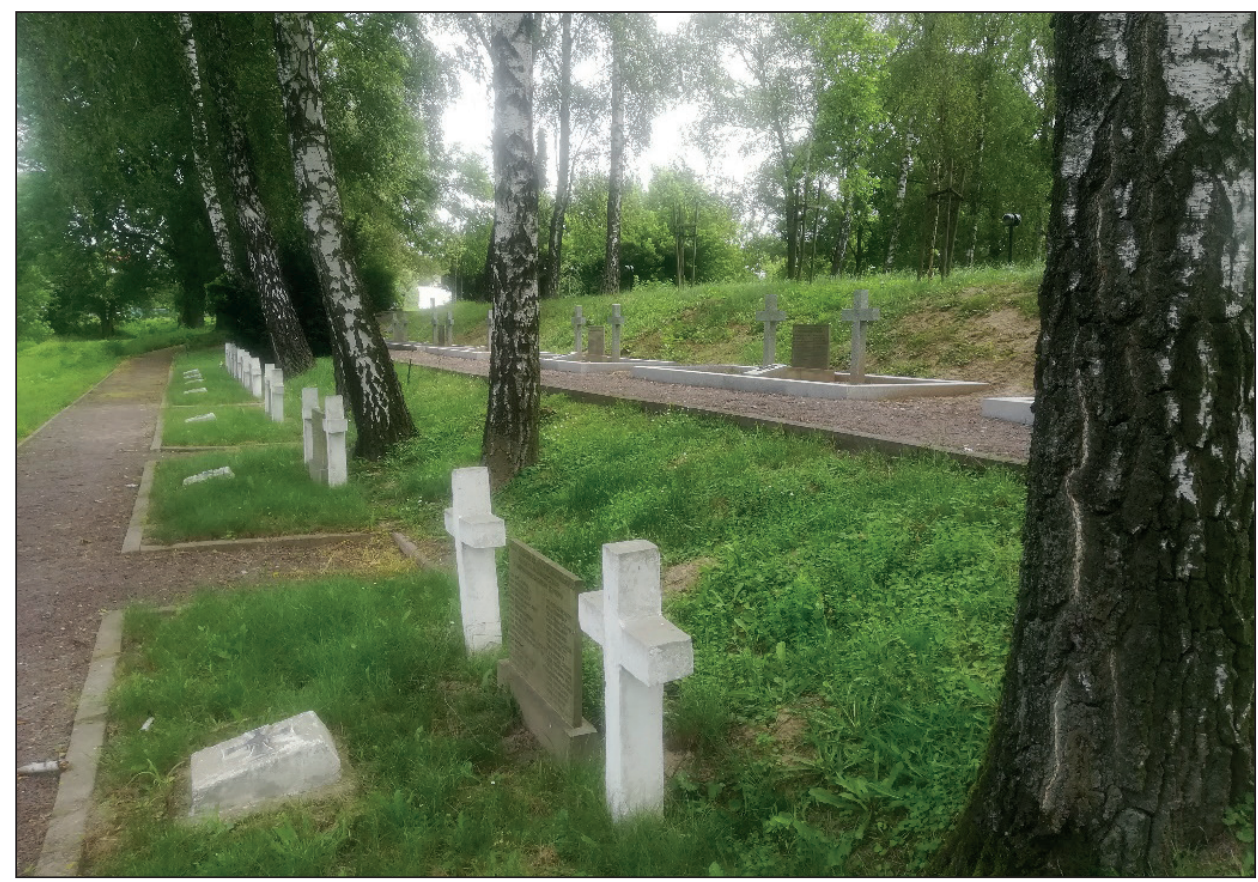

Fot. 2. Widok na mogiły poległych żołnierzy pochowanych na Rotundzie (fot. Ewa Koper, Zamość, 8 lipca 2020 r.).

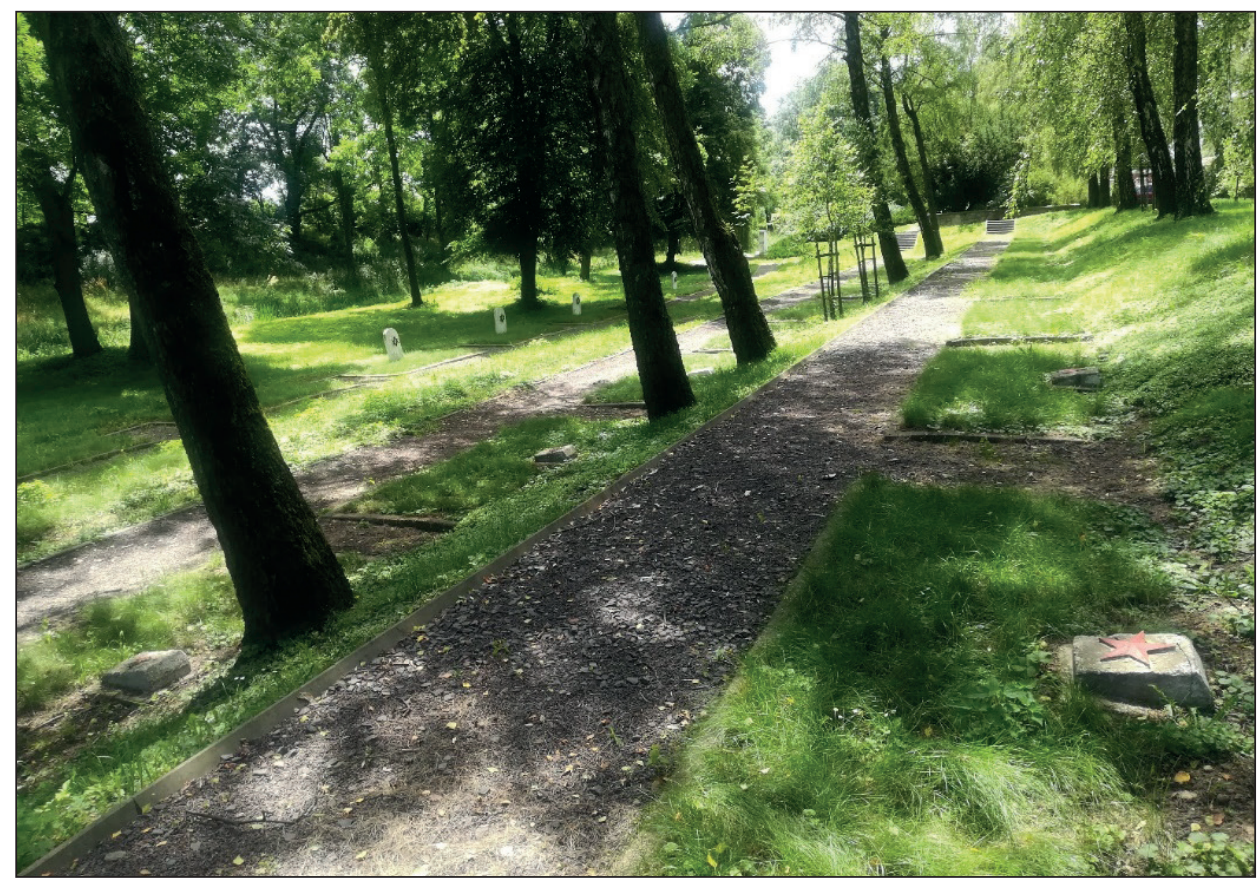

Fot. 3. Widok na mogiły żołnierzy sowieckich oraz ludności żydowskiej na Rotundzie (fot. Ewa Koper, Zamość, 8 lipca 2020 r.). 
W założeniach projektowych podkreślono, że obiekt ma znaczenie zabytku architektonicznego, będącego nieodłączną częścią twierdzy zamojskiej. Dodatkowo wydarzenia z lat okupacji niemieckiej „nadały mu rangę dokumentu historycznego

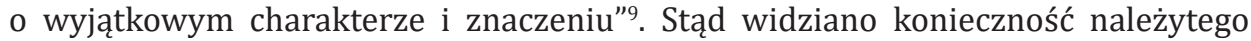
przygotowania obiektu do nowej roli jako placówki muzealnej, „którą bez ryzyka można byłoby nazwać pomnikiem martyrologii i walki Ziemi Zamojskiej”10. Już wtedy rozumiano też potrzebę przygotowania zespołu merytorycznego oraz zapewnienia stałego budżetu ${ }^{11}$.

W dniu 16 września 1944 r. odbyło się zebranie sekcji technicznej Komitetu Budowy Pomnika Mauzoleum „Rotunda”. Na czele sekcji stanął Adam Klimek. Członkowie reprezentowali m.in. Urząd Miasta i spółdzielnię „Beton”12. Plany i prace postępowały powoli. Do 2 lutego 1947 r. przygotowano projekt trzyletniego planu prac na Rotundzie, cmentarzysku Zamojszczyzny ${ }^{13}$. Wokół samej Rotundy pochowano ofiary zabite na miejscu i w więzieniu zamojskim. Po prawej stronie pochowano żołnierzy polskich i partyzantów, a po lewej żołnierzy sowieckich i Żydów ${ }^{14}$.

W toku prac zamierzano zachować historyczną bryłę dziewiętnastowiecznej budowli i zaadaptować ją na potrzeby tworzonego miejsca pamięci. Główną część, tj. działobitnię ${ }^{15}$, wraz z dziedzińcem i 19 celami, zamierzano uczynić strefą pamięci dla różnych grup ofiar ${ }^{16}$. Adaptując niewielkie przestrzenie cel, planowano zamknąć każdą z nich kratami dekoracyjnymi, a wewnętrzne okna oszklić. W celach zamierzano prezentować m.in. urny z prochami ofiar różnych obozów. Ten zamysł zrodził się w 1946 r., po przywiezieniu prochów pomordowanych z obozów koncentracyjnych na Majdanku i Auschwitz-Birkenau. Ponadto w jednej z cel zaplanowano urządzić kaplicę, a w kolejnych czterech ekspozycje muzealne ${ }^{17}$. Po zewnętrznej stronie muru (od rzeki) postanowiono wyrównać i podnieść poziom terenu. Wszystkie groby zamierzano obramować betonowymi krawężnikami, a drewniane krzyże zastąpić krzyżami z betonu. Dla podniesienia estetyki otoczenia zamierzono posadzić drzewa, główną aleję wysypać i utwardzić żużlem, zaś plac wyłożyć betonowymi płytkami ${ }^{18}$. Najprawdopodobniej dla podkreślenia wagi miejsca i gehenny mieszkańców regionu, planowano uczynić z Rotundy bardzo ukwiecone miejsce pamięci, o charakterze monumentalnym ${ }^{19}$.

9 APL, Protokoły z posiedzeń, plany pracy, informacje, plany obchodów rocznic 6.04 .1965 r. 31.12.1966 r., sygn. 265, b.p.

10 Ibidem, b.p.

11 Ibidem.

12 Byli to: inż. Jerzy Cymbaliński, Zbigniew Urbaniak, Klemens Tokarz, Wacław Ukleja, Eugeniusz Baranowski, Stanisław Milewski, Jan Kowlaski, Jerzy Czaplicki, Zbigniew Floryn, Józef Lenkiewicz, Klemens Tokarz, J. Jednac, Spozowski, Bednarski, Marszalec, Rogow - za: APZ, Starostwo Powiatowe w Zamościu, sygn. 784, k. 14.

13 Ibidem, sygn. 876, k. 7.

14 APL, Protokoły z posiedzeń, plany pracy, informacje, plany obchodów rocznic 6.04 .1965 r. 31.12.1966 r., sygn. 265, b.p.

15 Obiekt byłej działobitni pochodzi z I poł. XIX w., położony jest 600 m od Rynku w Zamościu.

16 Jedna cela została zniszczona podczas II wojny światowej.

17 APZ, Starostwo Powiatowe w Zamościu, sygn. 876, k. 7.

18 Ibidem, k. 7.

19 Ibidem, k. 8. 
Tak szeroko zakrojona obywatelska inicjatywa utworzenia cmentarza wojennego na Rotundzie spotkała się z brakiem poparcia ze strony miejscowych władz. Zarząd Miejski w Zamościu odmówił w marcu 1946 r. współpracy z KBPM „Rotunda”, motywując tę decyzję brakiem środków finansowych oraz powinnością inwestowania we własne cele i zadania ${ }^{20}$.

Kwestie finansowania były kluczowe dla powodzenia całego przedsięwzięcia. Środki na prace budowlane i porządkowe pozyskiwano zatem ze zbiórek ulicznych, organizowanych imprez oraz ze sprzedaży broszur ${ }^{21}$. Jedną z takich inicjatyw podjęto m.in. w okresie poprzedzającym Święta Wielkanocne w 1947 r. Sekretarz KBPM „Rotunda” wygłosił wtedy komunikat przez radiowęzeł w Zamościu. Mówił m.in.: „Tradycyjnym zwyczajem w dzień Wielkiego Piątku Komitet Budowy Pomnika Mauzoleum »Rotunda « urządza zbiórkę uliczną i na listy, celem zasilenia funduszów na dalsze kontynuowanie, a może już i wykończenie w bieżącym roku robót na Rotundzie. Zrobiono już wiele, lecz jeszcze wiele pozostało do zrobienia. Apelujemy przeto do społeczeństwa znanego z ofiarności. Nie szczędźcie ofiar. Nie odtrącajcie kwestujących. Grono ludzi dobrej woli, a szczególnie młodzież, która obecnie ściśle współpracuje z Komitetem, wyruszy jutro na ulice miasta Zamościa. Będzie pukać do serc waszych. Otwórzcie je"22. Można przypuszczać, że kwestujący spotykali się też z niechęcią części społeczeństwa, bowiem w dalszej treści komunikatu padły następujące słowa: „Często słyszy się głosy, iż trzeba pamiętać przede wszystkim o żywych. Tak - to prawda. I o żywych - tych maluczkich, sierotach, dzieciach przyszłości Narodu zapomnieć nam nie wolno. (...) i zwrócę się z apelem o składanie darów w naturze, na urządzenie święconego sierotom, których rodzice w niejednym przypadku właśnie na Rotundzie zginęli, malutkim lokatorom Domu Dziecka Nr 3 przy Powiatowym Komitecie Opieki Społecznej w Zamościu (...)”23. Nie udało się odnaleźć protokołów stwierdzających ilość zgromadzonych w ten sposób funduszy.

Z częściowo zachowanej dokumentacji można wnioskować, że Komitet potrzebował znacznych środków finansowych. Przykładowo, w 1946 r. koszt ekshumacji i przygotowania pogrzebu 400 ofiar oszacowano na 800 tys. złotych, robót budowlanych na 150 tys., przygotowanie krzyży i napisów - 480 tys., urządzenie mogił 1600000 zł, wykonanie bramy - 80 tys., wykonanie krat i ram okiennych - 240 tys. zł. Łącznie koszty wyniosły w 1946 roku 3350000 zł, w 1947 roku - 3350000 , a w 1949 roku - 4310000 zł²4. W celu zmniejszenia kosztów pochówku osób niezidentyfikowanych postulowano już jesienią 1946 r. rezygnację z trumien i używanie do przewozu ekshumowanych zwłok skrzyni o wymiarach: 1,50 m dł., 0,70 m szer., 0,60 m wys., z pokrywą i wnętrzem wybitym blachą ${ }^{25}$.

${ }^{20}$ Ibidem, sygn. 785, k. 11.

21 APL, Urząd Wojewódzki Lubelski, Wydział Odbudowy, Oddz. I, Ref. Gr.W I/1945/46/47 r., Sprawy ewidencji i opieki nad grobami wojennymi, Zamość, sygn. 227, k. 25.

22 APZ, Starostwo Powiatowe w Zamościu, sygn. 784, k. 17.

23 Ibidem, k. 17-18.

${ }^{24}$ Ibidem, sygn. 876, k. 7, 8.

25 APL, Urząd Wojewódzki Lubelski, Wydział Odbudowy, Oddz. I, Ref. Gr.W I/1945/46/47 r., Sprawy ewidencji i opieki nad grobami wojennymi, Zamość, sygn. 227, k. 35. 
Tabela 1. Wykaz ekshumacji przeprowadzonych na Rotundzie w latach 1944-1945

\begin{tabular}{|c|c|c|c|}
\hline Lp. & Data ekshumacji & Liczba wydobytych zwłok & Numer grobu na planie \\
\hline 1. & 25.07 .1944 & 1 & 13 \\
\hline 2. & 5.09 .1944 & 1 & 1 \\
\hline 3. & 8.09 .1944 & 7 & 2 \\
\hline 4. & 12.09 .1944 & 64 & 3 \\
\hline 5. & 14.09 .1944 & 30 & 6 \\
\hline 6. & 19.09 .1944 & 10 & 5 \\
\hline 7. & 26.10 .1944 & 44 & 5 \\
\hline 8. & 20.11 .1944 & 28 & 4 \\
\hline 9. & 20.11 .1944 & 8 & 7,9 \\
\hline 10. & 2.07 .1945 & 33 & 12 \\
\hline 11. & 2.07 .1945 & 3 & 10,11 \\
\hline 12. & 2.07 .1945 & 74 & 12 \\
\hline
\end{tabular}

Źródło: APL, Urząd Wojewódzki Lubelski, Wydział Odbudowy, Oddz. I, Ref. Gr.W I/1945/46/47 r., Sprawy ewidencji i opieki nad grobami wojennymi, Zamość, sygn. 227, k. 42.

Dane ujęte w powyższej tabeli, choć przybliżają skalę wykonanych ekshumacji, nie oddają rozmiaru indywidualnych tragedii zamordowanych osób i ich rodzin. Przeprowadzenie ekshumacji pozwoliło jednak na oszacowanie skali zbrodni i poznanie tożsamości części ofiar. Przykładem może być m.in. otwarcie grobu usytuowanego na prawo od wejścia na Rotundę. W jamie grobowej znaleziono 161 zwłok, w tym kobiet w ciąży i dzieci. Ciała sfotografowano i dokładnie opisano przed pochówkiem, który miał nastąpić 17 listopada 1946 r. ${ }^{26}$ Nadmienić należy, że KBPM „Rotunda”. przeprowadzał ekshumacje zgodnie z wytycznymi Ministerstwa Odbudowy i przy współudziale komisji sądowo-lekarskiej, prokuratora z ramienia Komisji Badań Zbrodni Niemieckich oraz przedstawiciela Polskiego Czerwonego Krzyża ${ }^{27}$.

Całość kompleksu Rotundy obejmowała 67257 metrów kwadratowych ${ }^{28}$. Na jej powierzchni wyodrębniono trzy strefy, czyli teren wraz z cmentarzem, budynek oraz prowizoryczną ekspozycję ${ }^{29}$. Wiosną 1947 r. działalność Komitetu „Rotunda” rozszerzono na cały powiat, obejmując opieką groby uczestników „walk o demokrację i niepodległość" ${ }^{30}$. Nie oznaczało to jednak wejścia w łatwiejszy okres działalności.

26 Ibidem, k. 44-45.

27 Ibidem, k. 43.

28 APL, Protokoły z posiedzeń, plany pracy, informacje, plany obchodów rocznic 6.04.1965 r. 31.12.1966 $r$, sygn. 265, b.p.

29 Groblę i otoczenie budynku wykonano zgodnie z dokumentacją opracowaną przez Biuro Projektów Gospodarki Komunalnej w Warszawie w 1955 r. - za: Ibidem, b.p.

30 APZ, Starostwo Powiatowe w Zamościu, sygn. 876, k. 24. 
Przyśpieszenie prac na Rotundzie nastąpiło w związku z planowanym nadaniem sztandaru miejscowemu pułkowi ${ }^{31}$ Wojska Polskiego oraz Krzyża Grunwaldu miastu Zamość. Starostwo powiatowe zaplanowano większą część uroczystości właśnie na Rotundzie w dniu 22 lipca 1947 r. ${ }^{32}$ Po licznych zabiegach otwarto muzeum na Rotundzie w kwietniu 1947 r., a ekspozycję - 8 września 1948 r. ${ }^{33}$ Otwarcie muzeum nastąpiło jednak w czasie, kiedy obiekt wciąż był własnością wojska.

Z prawnego punku widzenia bardzo istotne było uregulowanie kwestii własności obiektu. Starania trwały do 1948 roku. Uporządkowanie istniejącego stanu poprzedziły liczne zabiegi, których ślady znajdują się w dokumentacji archiwalnej ${ }^{34}$. Zarząd miejski już w 1945 r. wystąpił z prośbą o przekazanie Rotundy na cmentarz wojenny i skreślenie jej tym samym z ewidencji nieruchomości wojskowych. Prośba pozostała wtedy bez odpowiedzi. Jesienią 1945 r. zajęli Rotundę żołnierze Armii Czerwonej, którzy po dwóch tygodniach, wskutek interwencji Komitetu, w październiku puścili obiekt ${ }^{35}$. Ostatecznie, 3 października 1948 r. Urząd Wojewódzki w Lublinie przesłał dwa odpisy dotyczące przekazania obiektu wojskowego „Rotunda” do Starostwa Powiatowego i Komitetu Pomnika Mauzoleum „Rotunda” w Zamościu ${ }^{36}$. Ta decyzja otworzyła nowy etap funkcjonowania tego obiektu, jednak istotne zmiany nastąpiły dopiero w latach 60. XX wieku. Wcześniej, w 1949 r. zamierzano przygotować dwie cele dla upamiętnienia poległych partyzantów ${ }^{37}$. Miało to związek z powołaniem Związku Bojowników o Wolność i Demokrację. W jednej z cel planowano ustawić pomnik poświęcony poległym partyzantom, a w drugiej umieścić pamiątki dotyczące walk partyzanckich z Niemcami. Przygotowania wsparł Urząd Wojewódzki w Lublinie ${ }^{38}$.

Warto również wspomnieć, że pod koniec lat 50. w regionie ekshumowano bardzo wiele ofiar zbrodni niemieckich i pochowano je na Rotundzie w Zamościu. Szczątki ludzkie przywieziono z różnych miejscowości, także spoza Zamojszczyzny. W 1958 r. pochowano na Rotundzie szczątki co najmniej 1117 osób. Były to ciała żołnierzy polskich i sowieckich, ofiary niemieckich pacyfikacji i represji oraz ludności żydowskiej i romskiej ${ }^{39}$. Przywieziono je z następujących miejscowości:

31 Najprawdopodobniej chodzi o 8. Bydgoski Pułk Piechoty, który stacjonował w Zamościu w latach 1946-1950, zob. http://www.zamosciopedia.pl/index.php/ga-gd/item/4620-garnizon-po-1944, dostęp 14 IV 2019.

32 APZ, Starostwo Powiatowe w Zamościu, sygn. 876, k. 39, 40.

33 Zob. http://www.zamosciopedia.pl/index.php/ro-rr/item/3537-rotunda-mauzoleum-martyrologii-zamojszczyzny, dostęp 17 IV 2019.

34 W sprawę byli zaangażowani: Zarząd Miejski w Zamościu, Urząd Wojewódzki w Lublinie, Komendant Garnizonu, Ministerstwo Obrony Narodowej.

35 APL, Urząd Wojewódzki Lubelski, Wydział Odbudowy, Oddział I, Rok 1949. Ref. AB VI, Ewidencja, porządkowanie i opieka nad grobami wojennymi oraz poszukiwania i ekshumacje zwłok poległych pow. Zamość, sygn. 228, k. 8, 9.

36 Ibidem, k. 7.

37 Ibidem, k. 27.

38 Ibidem, k. 35.

39 Archiwum Polskiego Czerwonego Krzyża [dalej: APCK], Lista strat PCK, sygn. 23039, s. 22, 23; ibidem, sygn. 24826, s. 401, 404, 405, 407, 409, 412-433; ibidem, sygn. 23072, s. 144, 146, 149, 150, 151, 152, 153; ibidem, sygn. 22960, s. 369, 370, 371, 374, 375, 376, 377, 384; ibidem, sygn. 23033, s. 477, 478, 479, 480, 481, 482, 483, 484, 485, 486, 487, 488, 489. 
- Łabuńki, powiat zamojski - ciało polskiego żołnierza poległego w 1939 r., zwłoki spoczywały na cmentarzu wojennym z 1914 r.;

- Kalinowice, powiat zamojski - ciało żołnierza AK, poległego w 1944 r., zwłoki spoczywały na polu;

- Dachnów, powiat lubaczowski - 5 ciał polskich żołnierzy poległych w 1939 r., zwłoki spoczywały pod lasem i we wsi;

- Hrynków, powiat lubaczowski - 6 ciał Żydów rozstrzelanych przez Niemców w 1943 r., zwłoki spoczywały na polu koło wsi;

- Cieszanów, powiat lubaczowski - 8 ciał polskich żołnierzy poległych w 1939 r., zwłoki spoczywały na cmentarzu katolickim;

- Tymce, powiat lubaczowski - ciało polskiego żołnierza poległego w 1939 r., zwłoki spoczywały w lesie;

- Narol, powiat lubaczowski - ciało polskiego żołnierza poległego w 1939 r., zwłoki spoczywały na cmentarzu katolickim;

- Krasnobród, powiat zamojski:

- 98 ciał Żydów rozstrzelanych przez Niemców w 1942 r., zwłoki spoczywały obok rynku,

- 15 ciał Żydów rozstrzelanych przez Niemców w 1942 r., zwłoki spoczywały w lasku obok tartaku,

- 118 ciał Żydów rozstrzelanych przez Niemców w 1942 r., zwłoki spoczywały obok mleczarni;

- Podklasztor (dawna wieś, obecnie część Krasnobrodu):

- 60 ciał Żydów rozstrzelanych przez Niemców w 1942 r., zwłoki spoczywały za wsią, nad rzeką Wieprz,

- ciało żołnierza sowieckiego pochowanego w 1944 r., zwłoki spoczywały obok budynku parafialnego,

- 5 ciał polskich partyzantów rozstrzelanych przez Niemców w 1942 r., zwłoki spoczywały obok budynku parafialnego;

- Bondyrz, powiat zamojski - 3 ciała polskich partyzantów poległych w 1943 r., zwłoki spoczywały w lesie obok młyna;

- Potoczek, Adamów, Szewnia, powiat zamojski - 50 ciał Żydów zamordowanych przez Niemców w 1942 r. W Szewni Żydzi zostali rozerwani granatami. Zwłoki spoczywały we wsi Potoczek, pod lasem we wsi Adamów, obok leśniczówki we wsi Szewnia;

- Lipsko-Polesie - 44 ciała Polaków rozstrzelanych przez Niemców w 1943 r., zwłoki spoczywały koło wsi;

- Horyszów Polski, powiat zamojski - 25 ciał Żydów rozstrzelanych przez Niemców w 1942 r., zwłoki spoczywały obok cmentarza katolickiego;

- Hucisko, powiat zamojski - 3 ciała Polaków zamordowanych przez Niemców 1943 r., zwłoki spoczywały na terenie prywatnego ogrodu;

- Malewszczyzna, powiat zamojski - 4 ciała polskich partyzantów poległych w 1943 r., zwłoki spoczywały w lesie obok zabudowań wiejskich;

- Surhów, powiat krasnostawski - 3 ciała żołnierzy sowieckich poległych w 1944 r., zwłoki spoczywały przy polnej drodze;

- Olszanka, powiat krasnostawski:

- 2 ciała mieszkańców rozstrzelanych przez Niemców podczas pacyfikacji wsi, zwłoki spoczywały na wiejskim pastwisku, 
- 4 ciała Polaków rozstrzelanych przez Niemców w 1944 r., zwłoki spoczywały w prywatnym ogrodzie,

- 5 ciał Polaków rozstrzelanych przez Niemców podczas pacyfikacji wsi, zwłoki spoczywały w prywatnym ogrodzie obok szkoły,

- 2 ciała żołnierzy sowieckich poległych w 1944 r., zwłoki spoczywały na polu,

- ciało żołnierza sowieckiego poległego w 1944 r., zwłoki spoczywały w prywatnym ogrodzie;

- Kolonia Płonka, powiat krasnostawski - 2 ciała żołnierzy sowieckich zabitych w 1943 r., zwłoki spoczywały w lesie przy skrzyżowaniu dróg z Kolonii Płonka do wsi Płonka;

- Białka, powiat krasnostawski - zwłoki żołnierza polskiego poległego w 1939 r., zwłoki spoczywały przy drodze Krasnystaw - Żółkiewka;

- Namule, powiat krasnostawski - 4 ciała polskich partyzantów poległych w 1943 r., zwłoki spoczywały w lesie przy szosie Krasnystaw - Gorzków;

- Bereść, powiat zamojski - 5 ciał ofiar terroru, zwłoki spoczywały na cmentarzu prawosławnym (wcześniej greckokatolickim);

- Jarosławiec, powiat zamojski - 4 ciała polskich partyzantów, zwłoki spoczywały w lesie;

- Zamość - ciało żołnierza sowieckiego, zwłoki spoczywały na cmentarzu prawosławnym;

- Zamość - ciało żołnierza sowieckiego, zwłoki spoczywały na cmentarzu prawosławnym;

- Zamość - ciało żołnierza sowieckiego, zwłoki spoczywały na cmentarzu prawosławnym;

- Zamość - 2 ciała żołnierzy sowieckich, zwłoki spoczywały na cmentarzu prawosławnym;

- Zamość - 35 ciał żołnierzy sowieckich, zwłoki spoczywały na cmentarzu prawosławnym;

- Lisie Jamy, powiat lubaczowski - 18 ciał (czaszki, szczątki) Romów rozstrzelanych przez Niemców w 1941 r., zwłoki spoczywały w lesie „Niwki” ${ }^{40}$;

- Lubaczów - 6 ciał polskich żołnierzy poległych w 1939 r., zwłoki spoczywały na cmentarzu z I wojny światowej obok szpitala;

- Lubaczów - 6 ciał polskich żołnierzy poległych w 1939 r., zwłoki spoczywały przy torze kolejowym;

- Niwki, powiat lubaczowski - 32 ciała Romów rozstrzelanych przez Niemców w 1942 r., zwłoki spoczywały w zbiorowej mogile;

- Bałaje, powiat lubaczowski - 84 ciała Romów rozstrzelanych przez Niemców w 1942 r., zwłoki spoczywały w lesie;

- Werchrata, powiat lubaczowski - 117 ciał pasażerów pociągu zbombardowanego we wrześniu 1939 r., zwłoki spoczywały przy nasypie kolejowym;

- Smoryń, powiat biłgorajski - ciało polskiego żołnierza poległego w 1939 r., zwłoki spoczywały na cmentarzu z I wojny światowej;

${ }^{40}$ W źródle jako miejsce spoczynku po ekshumacji wskazano cmentarz żydowski w Zamościu. Ta informacja wydaje się mało prawdopodobna, bowiem dwa cmentarze żydowskie w Zamościu w $1958 \mathrm{r}$. były nieczynne, a ich teren zdesakralizowano. 
- Janów Lubelski - 112 ciał cywilów i żołnierzy poległych w czasie bombardowania miasta i walk prowadzonych na jego terenie w okresie II wojny światowej;

- Obrocz, powiat zamojski:

- ciało sowieckiego partyzanta poległego w 1942 r., zwłoki spoczywały w lesie od strony wsi Wojda,

- 10 ciał Żydów zamordowanych przez Niemców w 1942 r., zwłoki spoczywały w lesie od strony przysiółka Bór-Kosobudy,

- ciało polskiego partyzanta poległego w 1944 r., zwłoki spoczywały w lesie „Czworkowo”;

- Zwierzyniec, powiat zamojski - 4 ciała Żydów zamordowanych przez Niemców w 1944 r., zwłoki spoczywały w rowie pod lasem, w odległości około 100 m od rzeźni;

- Szczebrzeszyn, powiat zamojski:

- 7 ciał Żydów zamordowanych przez Niemców w 1942 r., zwłoki spoczywały na terenie prywatnego ogrodu,

- ciało Żyda zabitego przez Niemców w 1943 r., zwłoki spoczywały na łące;

- Sułów, powiat zamojski - 40 ciał Żydów zamordowanych przez Niemców w 1942 r., zwłoki spoczywały na wygonie wsi, na zboczu wzgórza między łąkami;

- Michalów, powiat zamojski - 6 ciał Żydów zamordowanych przez Niemców w 1942 r., zwłoki spoczywały w lesie przy drodze do Deszkowic Drugich;

- Nielisz, powiat zamojski:

- 18 ciał Żydów zamordowanych przez Niemców w 1943 r., zwłoki spoczywały na prywatnym podwórzu oraz na polu,

- 15 ciał Żydów zamordowanych przez Niemców w 1943 r., zwłoki spoczywały w lesie około 200 m od Nielisza, koło leśniczówki, w stronę Wielączy,

- 4 ciała Żydów zamordowanych przez Niemców w 1942 r., zwłoki spoczywały na polu;

- Wysokie, powiat zamojski:

- 3 ciała Żydów zamordowanych przez Niemców w 1942 r., zwłoki spoczywały w Borku Sitanieckim,

- 9 ciał ofiar terroru niemieckiego, zwłoki spoczywały na poligonie koło Wysokiego.

Żydzi stanowili największą grupę narodowościową, której szczątki przeniesiono na Rotundę - łącznie około 480 ciał. Drugą grupę, trudną do pełnej identyfikacji narodowościowej, stanową cywile zabici podczas bombardowania pociągu oraz jednego z miast w regionie, było to blisko 250 osób. Niewątpliwe jednak pochówek szczątków wszystkich tych ofiar na Rotundzie uchronił je od profanacji i potencjalnego zapomnienia.

Podobnie jak w przypadku innych upamiętnień, również względem Rotundy nie podejmowano po 1950 r. czynności remontowych czy modernizacyjnych w szerszym zakresie $^{41}$. W połowie lat 60 . XX w. rozpoczęto kolejne prace w samym obiekcie i wo-

41 Zob. http://www.zamosciopedia.pl/index.php/ro-rr/item/3537-rotunda-mauzoleum-martyrologii-zamojszczyzny, dostęp 17 IV 2019. 
kół niego. 6 października 1965 r. odbyło się posiedzenie Prezydium Rady Ochrony Pomników Walki i Męczeństwa w Zamościu. Przedmiotem dyskusji było urządzenie stałej wystawy na Rotundzie i zagospodarowanie jej otoczenia ${ }^{42}$. Prace podzielono na dwa etapy. W pierwszej fazie zamierzano wykonać drogę dojazdową z chodnikami, wybudować budynek administracyjny i mieszkalny dla dozorcy, studnię, zbiornik na szambo, położyć sieć elektryczną, przygotować ekspozycję muzealną i zagospodarować zieleń wokół Rotundy. Podczas etapu drugiego zakładano kontynuowanie prac nad urządzeniem zieleni wokół Rotundy oraz prace melioracyjne przy fosie ${ }^{43}$.

Nową ekspozycję planowano otworzyć we wrześniu 1966 r. $^{44}$ Wydział Kultury Prezydium Wojewódzkiej Rady Narodowej w Lublinie zlecił opracowanie wytycznych. Zespół autorski, który tworzyli Edward Dziadosz, Edward Gryń i Zofia Murawska, stanął przed niełatwym zadaniem. W znacznej mierze aranżację obiektu ograniczał jego wojskowy charakter ${ }^{45}$. Przyjęto więc, że nowa ekspozycja będzie składać się z prostych i dużych form plastycznych na luźno stojących konstrukcjach. W sposób minimalistyczny zabudowano cele, z uwzględnieniem takich trudności, jak brak dostatecznej ilości światła naturalnego, mała funkcjonalność pomieszczeń czy wąskie przejścia ${ }^{46}$.

Poddano pod dyskusję kluczowe kwestie związane z kształtem planowanej ekspozycji. W pierwszym założeniu zamierzano ograniczyć ją do ukazania Rotundy jako miejsca martyrologii i jej związku z Zamościem, w drugim zaś rozszerzyć w formie „martyrologia i walka Zamojszczyzny” ${ }^{47}$. Ostatecznie wybrano wariant drugi, ze względu na brak dostatecznych źródeł dotyczących samej Rotundy ${ }^{48}$.

W planach przebudowy ekspozycji zalecono skucie tynków, podłogi w celi nr 14 oraz odkucie zamurowanych przejść, by przywrócić oryginalny wygląd budowli. $\mathrm{Na}$ ekspozycji zamierzano pokazać również wysiedlenia, pacyfikacje, losy dzieci i walkę z okupantem niemieckim. Elementy takie, jak pomniki, tablice, nagrobki, planowano przenieść do „celi pamięci”, ze względu na to, że „stanowią wyraz serdecznego odruchu społeczeństwa i są dowodem pamięci o pomordowanych"49.

Przy drugim urządzeniu miejsca zastosowano nowe rozwiązania, tj. od strony zewnętrznej wmurowano w dwóch równoległych rzędach wypukłe bloki kamienne z nazwiskami zaginionych, na słupach bramnych ustawiono rzeźby orłów zrywających się do lotu, a na dziedzińcu wzniesiono pomnik oraz wykonano krzyż cementowy o wysokości 8 metrów ${ }^{50}$. Kolejnym krokiem nowej aranżacji było ustawienie przy murach 18 otynkowanych słupów murowanych, symbolizujących SS-manów.

42 APL, Protokoły z posiedzeń, plany pracy, informacje, plany obchodów rocznic 6.04.1965 r. 31.12.1966 r., sygn. 265, b.p.

43 Ibidem, b.p.

44 Ibidem.

45 Cele były wybudowane w układzie radialnym w rozmiarach: długość 5,20 m oraz szerokość 3,5 m i 5 m (od strony dziedzińca). Okna były strzelnicze, wąskie i okratowane. Drzwi od dziedzińca miały wymiary $100 \times 200 \mathrm{~cm}$, a wewnętrzne przejścia bez drzwi $-1,60 \mathrm{~m}$. Sufity w celach były typu kolebkowego, a podłoga niemal wszędzie była klepiskiem. Tylko w jednej celi była wyłożona cementowymi płytkami - zob. Ibidem, b.p.

46 Ibidem, b.p.

47 Ibidem.

48 Ibidem.

49 Ibidem.

50 Ibidem. 
Słupy obsadzono krzewami dzikiego wina. Na gruzach celi nr 1, gdzie rozstrzeliwano więźniów, umieszczono tablicę informującą o charakterze tego miejsca. Dla dodania ruinie ekspresji otoczono ją drutem kolczastym. Kolejną celę wykorzystano jako magazyn dozorcy, a pozostałe oddano do dyspozycji stowarzyszeniom i instytucjom zamojskim, które miały przygotować poszczególne sale pamięci i upamiętnić martyrologię wojenną różnych grup społecznych ${ }^{51}$. I tak, celę nr 3 poświęcono powstańcom warszawskim, nr 4 - więźniom obozów koncentracyjnych, nr 5 - więźniom politycznym, nr 6 - zamordowanym kupcom, nr 7 - zamordowanym harcerzom, nr 8 - pamięci pomordowanych na Majdanku i w Zamku Lubelskim, nr 9 - „upamiętniono na sposób sakralny” martyrologię duchowieństwa, nr 10 - przeznaczono pamięci pomordowanych w Auschwitz, nr 11 - zamordowanym pocztowcom, nr 12 - nauczycielom, nr 13 - partyzantom Ziemi Zamojskiej, nr 14 - spółdzielcom. Pięć ostatnich cel przeznaczono na niewielką ekspozycję związaną z historią Rotundy i Zamojszczyzny w okresie okupacji ${ }^{52}$. W latach następnych w jednej z tych cel upamiętniono Polaków zesłanych na Syberię ${ }^{53}$.

W 1992 r. cela poświęcona powstańcom warszawskim została przekształcona w miejsce poświęcone zamordowanym na Wołyniu ${ }^{54}$. Ten zabieg ośmielił prezesa Koła Krzemieńczan z Warszawy do rozpoczęcia starań o upamiętnienie na Rotundzie również losów mieszkańców Krzemieńca zamordowanych przez Ukraińską Powstańczą Armię. Andrzej Przewoźnik, ówczesny sekretarz Rady Ochrony Pamięci Walk i Męczeństwa, podjął decyzję, by sprawę skierować do zarządzających Rotundą, czyli Prezydenta Miasta Zamościa oraz Wojewódzkiego Konserwatora Zabytków. Ostatecznie postulaty te nie zostały zrealizowane. Komitet Rady Ochrony Pamięci Walk i Męczeństwa w Zamościu poinformował, że w celi upamiętniającej rzeź na Wołyniu jest herb Krzemieńca, a umieszczenie nowej tablicy wymagałoby dostosowania jej do już tam obecnych oraz zorganizowania wizji lokalnej z udziałem podmiotów odpowiedzialnych za Rotundę ${ }^{55}$.

Nie wszyscy jednak postępowali zgodnie z wymogami proceduralnymi. Do samowolnych działań doszło w październiku 1994 r. Bez uzgodnień z Urzędem Miasta i Komitetem Ochrony Pamięci, zaadaptowano jedną z cel. Inicjatorem samozwańczej inicjatywy był Światowy Związek Żołnierzy Armii Krajowej Okręg w Zamościu. Przedstawiciele związku zamontowali imienne tablice, bez wpisania danych poległych do ewidencji ${ }^{56}$.

Również w latach dziewięćdziesiątych, obok kwatery ofiar zbrodni niemieckich, żołnierzy poległych we wrześniu 1939 r., żołnierzy Armii Krajowej, żołnierzy Armii Czerwonej, ofiar ludności żydowskiej, pojawiła się kolejna kwatera - ofiar okresu stalinowskiego. Jej powstanie wiąże się z ekshumacją w 1989 r. i przeniesieniem na

51 Ibidem.

52 Ibidem.

53 Archiwum Delegatury Urzędu Wojewódzkiego w Zamościu [dalej: ADUWwZ], Działalność Wojewódzkiego Komitetu Ochrony Pamięci Walk i Męczeństwa, t. I, sygn. 77/10.

54 Zob. http://www.zamosciopedia.pl/index.php/ro-rr/item/3537-rotunda-mauzoleum-martyrologii-zamojszczyzny, dostęp 17 IV 2019.

55 ADUWwZ, Działalność Wojewódzkiego Komitetu Ochrony Pamięci Walk i Męczeństwa, nr 1-60, sygn. KST. 7061/96, b.p.

56 ADUWwZ, Działalność Wojewódzkiego Komitetu Ochrony Pamięci Walk i Męczeństwa, WKSiT, t. II 46-63, KSI. 7061/94, s. b.p. 
Rotundę szczątków 20 osób, zamordowanych w nieznanych okolicznościach w październiku 1947 r. w lasach koło Jacni ${ }^{57}$.

Podsumowując, można uznać bezsprzecznie, że społeczny trud podjęty w celu zachowania Rotundy był niezwykle ważny. Zadbano o historyczny budynek i tym samym doprowadzono do zachowania pamięci o tragicznych wydarzeniach. Było to miejsce, gdzie upamiętniano więzionych i zamordowanych mieszkańców regionu oraz miejsce, które urosło do rangi symbolu. W 2016 r. władze miejskie Zamościa ogłosiły, że Rotunda zostanie poddana rewitalizacji. Prace zakończono w drugiej połowie $2020 \mathrm{roku}^{58}$. Obiekt wraz całym otoczeniem poddano konserwacji i modernizacji. Dzięki temu miejsce martyrologii będzie przez kolejne dekady świadczyło o tragicznym losie ludności Polski w okresie II wojny światowej.

Po wojnie na Rotundzie pochowano bardzo wielu ludzi. Byli wśród nich zarówno mieszkańcy regionu, jak i osoby pochodzące z różnych części Polski, a także przedstawiciele innych państw, jak np. gen. Siergiej Jakowlewicz Ogurcow (1899-1942). Większość ofiar jest jednak bezimienna. Najpełniej znane są nazwiska poległych i zamordowanych żołnierzy polskich, którzy zostali ekshumowani z różnych miejsc na Zamojszczyźnie.

\section{LISTA ŻOŁNIERZY WOJSKA POLSKIEGO POLEGEYCH W KAMPANII WRZEŚNIOWEJ W 1939 ROKU}

\section{TABLICE ZBIOROWE}

STRZEL[EC] ${ }^{59}$ ADAMSKI HERBERT UR. 1911 † 24.09.1939 BIŁGORAJ, STRZEL. ANDRUT JÓZEF UR. 07.03.1906 † 23.09.1939 MAJDAN GÓRNY, STRZEL. ANTYKAŁO ALEKSANDER † 18.09.1939 ZWIERZYNIEC, MJR AST LEON UR. 20.05.1894 † 22.09.1939 CZEŚNIKI, STRZEL. AUGUŚCIUK B. † 19.09.1939 ZAMIANY, STRZEL. AZMANER NUCHYM † 19.09.1939 ZAMIANY, STRZEL. BABIK JAN † 20.09.1939 ZAMIANY, PLUT. PCHOR. BACIA MIECZYSŁAW † 18.09.1939 BIAŁY SŁUP, KPT. BARABASZ BRONISŁAW-IGNACY UR. 20.08.1909 † 19.09.1939 LIPSKO, PPOR. BARAN PIOTR UR. 26.06.1907 † 19.09.1939 LIPSKO, STRZEL. BARANIAK LUDWIK UR. 22.07.1899 † 19.09.1939 ZWIERZYNIEC, STRZEL. BASIŃSKI MARCIN † 18.09.1939 LIPSKO, STRZEL. BAZELAK JAN † 20.09.1939 MAJDAN GÓRNY, STRZEL. BĄK ANDRZEJ † 19.09.1939 ŁUSZCZACZ, JUNAK BEDNARSKI UR. 1921 † 15.09.1939 BIŁGORAJ, KPR. BEJGER EMERYK † 19.09.1939 ŁASOCHY

STRZEL. ADAMCZYK EDWARD † 23.09.1939 PODHUCIE, STRZEL. AMBROZIAK LEONARD † 23.09.1939 PODHUCIE, STRZEL. BARAŃSKI ANTONI †20.09.1939 MAJDAN WIELKI, STRZEL. BŁASZCZAK EDWARD † 23.09.1939 ZAMOŚĆ, STRZEL. BOGUSŁAWSKI BOLESŁAW † 23.09.1939 PODHUCIE, STRZEL. BYRDA JAN † 23.09.1939

\footnotetext{
57 ADUWwZ, Nadzorowanie organizowania i sprawowania opieki nad cmentarzami wojennymi i grobami poległych - Działalność WKOPWiM, sygn. 7061/91, b.p.

58 Zob. http://www.zamosc.eu/projekty/54/7/rewitalizacja_rotundy_zamojskiej_w_zamosciu.html, dostęp 5 V 2021.

59 W nawiasach kwadratowych tu i dalej uzupełnienia od redakcji.
} 
PODHUCIE, STRZEL. CIEŚLARCZYK MICHAŁ UR. 1913 † 23.09.1939 PODHUCIE, CISŁO ANTONI † 19.09.1939 ZAMOŚĆ, KPR. DANILEWICZ KAROL † 23.09.1939 PODHUCIE, STRZEL. DOWRÓZ EDWARD † 22.09.1939 MAJDAN WIELKI, STRZEL. DYMARCZYK STANISŁAW UR. 12.04.1916 † 20.09.1939 MAJDAN WIELKI, STRZEL. DZIECHCIOWSKI † 20.09.1939 MAJDAN WIELKI, STRZEL. DZIERUK JÓZEF † 23.09.1939 PODHUCIE, KPR. FIJAŁKOWSKI STANISŁAW UR. 1908 † 23.09.1939 MAJDAN WIELKI, STRZEL. GAŁĄZKA WŁADYSŁAW † 19.09.1939 MAJDAN WIELKI, STRZEL. GASECKI ALBIN † 23.09.1939 PODHUCIE

STRZEL. ALBRAM KAROL † 23.09.1939 HRUBIESZÓW, [...]AMOCKI ${ }^{60}$ JÓZEF † 19.09.1939 ULÓW, STRZEL. ANTONIUK WASYL UR. 1916 † 19.09.1939 ZIELONE, STRZEL. BAJCAR WINCENTY UR. 1908 † 18.09.1939 ZIELONE, BAŁABUCH STANISŁAW † 1944, STRZEL. BANACH JÓZEF † 19.09.1939 ULÓW, BARAŃSKI JAN † 1944 LASY POSADOWSKIE, STRZEL. BELT WŁADYSŁAW † 23.09.1939 TARNAWATKA, STRZEL. BERDECKI JAN UR. 31.01.1903 † 19.09.1939 ULÓW, STRZEL. BERKE PAWEŁ † 19.09.1939 ULÓW, STRZEL. BŁACHOCIŃSKI ANDRZEJ UR. 1918 † 19.09.1939 ULÓW, POLICJANT BŁOŃSKI PIOTR UR. 1901 † 14.09.1939 HRUBIESZÓW, PPOR. BOJARSKI ZBIGNIEW UR. 3.11.1912 † 29.09.1939 TARNAWATKA, STRZEL. BRAWANZKI TEOFIL UR. 1916 † 19.09.1939 ULÓW, STRZEL. BRESTERMAN FISZER † 18.09.1939 PAARY

ST. STRZEL. BERMANN ABRAHAM † 23.09.1939 PODLODÓW, STRZEL. BERTIG WILHELM † 23.09.1939 PODLODÓW, SZER. BETEJ DYMITR UR. 1906 † 20.09.1939 ZAMIANY, STRZEL. BICZYK FELIKS † 23.09.1939 MAJDAN GÓRNY, STRZEL. BIERCZAK FRANCISZEK † 16.09.1939 BIŁGORAJ, STRZEL. BIERNACKI ANTONI † 18.09.1939 ZWIERZYNIEC, STRZEL. BIERNAT ADAM UR. 14.10.1910 † 18.09.1939 LIPSKO, STRZEL. BILMAN PINKUS † 23.09.1939 MAJDAN GÓRNY, STRZEL. BOBER JAN UR. 1913 † 20.09.1939 MAJDAN GÓRNY, ST. SIERŻ. BOCHEŃSKI STANISŁAW † 18.09.1939 ZAMOŚĆ, ST. STRZEL. BOCHEŃSKI STANISŁAW † 18.09.1939 MAZIŁY, STRZEL. BOCIEK JAN UR. 1910 † 23.09.1939 PRZEWŁOKA, STRZEL. BOJDAK JÓZEF UR. 07.06.1915 † 19.09.1939 BEŁŻEC, STRZEL. BONDAR JAN † 15.09.1939 BIŁGORAJ, STRZEL. BORAŃCZUK WŁADYSŁAW † 20.09.1939 MAJDAN GÓRNY, KPR. BOROWIEC † 21.09.1939 LIPSKO

STRZEL. BORYS STANISŁAW † 20.09.1939 MAJDAN GÓRNY, STRZEL. BROL PAWEŁ † 20.09.1939 MAJDAN WIELKI, KPR. BRYLUSKI TOMASZ UR. 1911 † 19.09.1939 MAJDAN WIELKI, KPR. BRZAKALA STANISŁAW † 23.09.1939 PODLODÓW, KPR. BRZEZINA STANISŁAW † 18.09.1939 ZWIERZYNIEC, SAP[ER] BRZEZIŃSKI LEOPOLD † 19.09.1939 MAJDAN WIELKI, BUCHACZ JULIAN † 19.09.1939 MAZIŁY, STRZEL. CETTEL UR. 1917 † 18.09.1939 MAZIŁY, STRZEL. CHINOWSKI JAN † 23.09.1939 MAJDAN GÓRNY, MJR CHODOROWSKI TADEUSZ-JAN † 18.09.1939 ZWIERZYNIEC, STRZEL. CHOJECKI WŁADYSŁAW † 20.09.1939 ZWIERZYNIEC, KPR. CHOJNICKI TEOFIL † 23.09.1939 RACHANIE, STRZEL. CHORZEPO KAROL UR. 1913 † 19.09.1939 MAZIŁY, STRZEL. CHRAPLEWSKI LEON † 20.09.1939 ZWIERZYNIEC, STRZEL. CHROBAK EMANUEL † 18.09.1939 MAZIŁY

KAN[ONIER] BRUCZEWSKI † 23.09.1939 TARNAWATKA, STRZEL. BUDNY FRANCISZEK † 19.09.1939 ULÓW, CHOĆKO JAN † 02.06.1944, STRZEL. CHOLEWA BRONISŁAW † 19.09.1939 ULÓW, PPOR. CHORT STEFAN † 18.09.1939 PAARY, STRZEL.

60 Brak pierwszych liter w nazwisku. 
CHIRASZ STEFAN † 19.09.1939 ULÓW, STRZEL. CIELEPA ANTONI UR. 20.09.1915 † 19.09.1939 ULÓW, STRZEL. CIEŚLAK ADAM † 18.09.1939 ULÓW, STRZEL. CISOWSKI TADEUSZ † 19.09.1939 ULÓW, STRZEL. CYSZ FRANCISZEK † 19.09.1939 ULÓW, PPOR. CZAPLIŃSKI SZYMON MARIAN UR. 19.05.1915 † 18.09.1939 SZAROWOLA, PPOR. CZAPSKI JAN UR. 1908 † 07.10.1939 HRUBIESZÓW, STRZEL. CZARNIK BOLESŁAW UR. 21.02.1919 † 19.09.1939 ULÓW, STRZEL. CZARNOGA FRANCISZEK † 18.09.1939 ULÓW, STRZEL. CZCIONKA RUDOLF UR. 1909 † 18.09.1939 KUNKI, ST. STRZEL. CZERNIAK JÓZEF UR. 1911 † 19.09.1939 ZIELONE

STRZEL. CHWIST ANTONI † 23.09.1939 PODLODÓW, SZER. CIECHANOWICZ UR. 1912 † 01.10.1939 BIŁGORAJ, STRZEL. CIEPLAK MIECZYSŁAW † 29.09.1939 MAJDAN GÓRNY, POR. REZ. CIEPLAK ROMAN UR. 16.07.1894 † 19.09.1939 ZAMOŚĆ, STRZEL. CIEPLIK STANISŁAW UR. 1915 † 18.09. 1939 MAJDAN GÓRNY, STRZEL. CIEPŁY PAWEŁ † 18.09.1939 ZWIERZYNIEC, STRZEL. CISZEWSKI BRONISŁAW † 23.09.1939 MAJDAN GÓRNY, STRZEL. CYFKA EDMUND † 18.09.939 ZWIERZYNIEC, KPR. CYGIELBACH STANISŁAW † 29.09.1939 PODLODÓW, POR. CZAPOROWSKI JERZY-LUCJAN † 19.09.1939 PAŃSKA DOLINA, STRZEL. CZECH FRANCISZEK UR. 1915 † 19.09.1939 BEŁŻEC, STRZEL. CZECH FRANCISZEK † 23.09.1939 PODLODÓW, STRZEL. CZECHOWSKI JÓZEF † 18.09.1939 ZWIERZYNIEC, STRZEL. CZEKAJ JAN † 21.09.1939 LIPSKO, STRZEL. CZELUŚNIAK FRANCISZEK † 18.09.1939 MAZIŁY, KAN. CZERWONKA STANISŁAW † 20.09.1939 MAJDAN WIELKI

BOMB[ARDIER] DĘBOWSKI STANISŁAW † 18.09.1939 LIPSKO, STRZEL. DREWNOWSKI JULIAN UR. 1908 † 23.09.1939 RACHANIE NOWE, SZER. DUBOWIK ALEKSY UR. 1915 † 26.09.1939 BIŁGORAJ, STRZEL. DUDEK † 19.09.1939 BEŁŻEC, ST. SZER. DUDKA JÓZEF † 20.09.1939 ZAMIANY, KRP. DZIEBDZIELA STEFAN † 23.09.1939 RACHANIE, STRZEL. DZIEDZICKI MIKOŁAJ UR. 1915 † 25.09.1939 BIŁGORAJ, ST. STRZEL. DZIUBEK † 18.09.1939 ZAMOŚĆ, STRZEL. DZIUBEK EWALD UR. 1915 † 18.09.1939 MAZIŁY, KAN. DYLSKI FERDYNAND † 15.09.1939 BIŁGORAJ, SIERŻ. ERNEST FELIKS † 18.09.1939 LIPSKO, KPR. FILATIUK JAN † 21.09.1939 LIPSKO, STRZEL. FISZER ANTONI † 19.09.1939 BEŁŻEC, STRZEL. GABRYCH LEON UR. 1916 † 18.09.1939 ZWIERZYNIEC, SZER. GABRYCH LEON † 18.09.1939 ZWIERZYNIEC, PPOR. GABRYŚ JAN UR. 23.11.1913 † 23.09.1939 ZWIERZYNIEC

KPR. GADAWE JÓZEF UR. 10.11.1904 † 24.09.1939 BIŁGORAJ, STRZEL. GAJDA ERNEST † 18.09.1939 ŁASOCHY, STRZEL. GAJDUK JULIAN † 22.09.1939 PODHUCIE, PPOR. GAJEWSKI WACŁAW-JOACHIM UR. 1909 † 22.09.1939 CZEŚNIKI, STRZEL. GALUS KASPER-RYSZARD † 18.09.1939 ZWIERZYNIEC, STRZEL. GANC FRANCISZEK † 18.09.1939 MAZIŁY, STRZEL. GARBARCZYK FRANCISZEK † 18.09.1939 ZWIERZYNIEC, STRZEL. GAWALD BOLESŁAW UR. 16.06.1916 † 20.09.1939 ZAMIANY, GEDLEK FRANCISZEK UR. 1906 † 22.09.1939 BIŁGORAJ, STRZEL. GOJNY WIKTOR † 18.09.1939 MAZIŁY, PPOR. GOLECKI STANISŁAW UR. 16.04.1912 † 18.09.1939 MAZIŁY, KPT. GOŁOGÓRSKI JERZY † 18.09.1939 ZWIERZYNIEC, STRZEL. GOTTSCHALK OSWALD † 20.09.1939 MAJDAN GÓRNY, STRZEL. GÓRAL CZESŁAW † 23.09.1939 RACHANIE, STRZEL. GÓRNY FELIKS † 20.09.1939 MAJDAN WIELKI, PLUT. GÓRNY KACPER +20.09 .1939 ZAMIANY

STRZEL. GÓROL PIOTR † 23.09.1939 RACHANIE, KPR. GÓRSZCZYK JÓZEF † 20.09.1939 MAJDAN WIELKI, ST. STRZEL. GROCHOWSKI MIECZYSŁAW † 18.09.1939 MAZIŁY, STRZEL. GRUDZIŃSKI † 18.09.1939 MAZIŁY, KAN. HENDEREK † 18.09.1939 
ZAMIANY, MJR HARLAND WŁADYSŁAW UR. 23.04.1897 † 23.09.1939 PODLODÓW, POR. HENDEFIK ANTONI-ZBIGNIEW UR. 01.06.1912 † 19.09.1939 BEŁŻEC, STRZEL. HNAT IGNACY s[yn] WINCENTEGO UR. 1914 † 07.10.1939 BIŁGORAJ, JADCZAK ALOJZY † 20.09.1939 ZAMIANY, STRZEL. JADWISIAK WŁADYSŁAW UR. 1904 † 23.09.1939 PRZEWŁOKA, STRZEL. JAKUBOWICZ ANTONI † 21.09.1939 LIPSKO, KAN. JAMROZ LUDWIK UR. 1901 † 02.10.1939 BIŁGORAJ, STRZEL. JANKOWSKI KAROL † 18.09.1939 MAZIŁY, STRZEL. JANKOWSKI MICHAŁ † 18.09.1939 MAZIŁY, ST. STRZEL. JANKOWSKI WACŁAW † 20.09.1939 MAJDAN GÓRNY, STRZEL. JANTAC KANTOR † 23.09.1939 PODLODÓW

STRZEL. KAROLAK JÓZEF † 23.09.1939 RACHANIE, KPR. KARPIŃSKI JAN † 13.09.1939 BIŁGORAJ, ST. STRZEL. KARUS JÓZEF UR. 28.02.1914 † 08.09.1939 ZWIERZYNIEC, PLUT. KAWALA STANISŁAW UR. 1905 † 20.09.1939 TOMASZÓW LUBELSKI, ST. STRZEL. KĘZIOR JAN † 23.09.1939 PODLODÓW, STRZEL. KĘDZIORA FRANCISZEK † 20.09.1939 ZAMIANY, STRZEL. KĘPA JAN † 20.09.1939 MAJDAN GÓRNY, PŁK. KLACZYŃSKI WACŁAW UR. 09.10.1887 † 19.09.1939 MAZIŁY, STRZEL. KLEPEK JÓZEF UR. 01.06.1912 † 20.09.1939 BIŁGORAJ, STRZEL. KLIS JAN UR. 23.12.1914 † 19.09.1939 BEŁŻEC, STRZEL. KMITA SZCZEPAN † 20.09.1939 MAJDAN GÓRNY, PPOR. KOKOT JÓZEF-MARIAN UR. 02.01.1912 † 21.09.1939 ZWIERZYNIEC, STRZEL. KOLEJ PIOTR UR. 1908 † 23.09.1939 MAJDAN GÓRNY, STRZEL. KOŁODZIEJCZYK JÓZEF † 19.09.1939 MAJDAN WIELKI, STRZEL. KOMALA EDWARD † 30.09.1939 BIŁGORAJ

KAN. KUNDZERUK JAN † 19.09.1939 ZAMIANY, STRZEL. KURKUS ZYGMUNT † 20.09.1939 MAJDAN GÓRNY, STRZEL. KURLIT JÓZEF † 18.09.1939 NAROL-WIEŚ, POR. KURTYKA JAN UR. 19.05.1895 † 23.09.1939 PODLODÓW, STRZEL. KURZYNIEC KONSTANTY UR. 1913 † 20.09.1939 LIPSKO, STRZEL. KUSTRA ROMAN † 23.09.1939 PODLODÓW, STRZEL. KUŚNIECKI MIECZYSŁAW † 23.09.1939 PODLODÓW, STRZEL. KWACIAK WŁADYSŁAW UR. 1915 † 19.09.1939 BEŁŻEC, ST. SIERŻ. KWIATKOWSKI WINCENTY UR. 1898 † 30.09.1939 BIŁGORAJ, STRZEL. KWICZAŁA FRANCISZEK 03.10.1939 BIŁGORAJ, STRZEL. KYC PAWEŁ † 18.09.1939 ZWIERZYNIEC, STRZEL. LABUS LEONARD UR. 16.02. 1914 † 19.09.1939 BEŁŻEC, LASKOSZ JAN UR. 1908 † 18.09.1939 MAZIŁY, STRZEL. LATUSIEWICZ JAN † 20.09.1939 MAJDAN GÓRNY, STRZEL. LENDZIN FRANCISZEK † 21.09.1939 LIPSKO, STRZEL. LENTOWSKI KAZIMIERZ † 23.09.1939 PODLODÓW.

KAN. LEWANDOWSKI ANTONI † 23.09.1939 ZAMIANY, STRZEL. LEWANDOWSKI MIECZYSŁAW † 18.09.1939 LIPSKO, STRZEL. LEWIŃSKI MARIAN UR. 10.06.1915 † 19.09.1939 BEŁŻEC, STRZEL. LITWIŃSKI ADAM † 19.09.1939 BEŁŻEC, STRZEL. LONDZIN FRANCISZEK † 18.09.1939 NAROL, PPOR. LORENZ FRANCISZEK UR. 09.09.1908 † 18.09.1939 ZAMOŚĆ, STRZEL. ŁUKASIK ANTONI UR. 1916 † 20.09.1939 MAJDAN GÓRNY, STRZEL. ŁYSZCZ MIECZYSŁAW † 23.09.1939 PODLODÓW, STRZEL. ŁYSZCZARZ ANTONI † 19.09.1939 BEŁŻEC, STRZEL. MACIEJEWSKI ADOLF UR. 01.02.1912 † 18.09.1939 LIPSKO, PPOR. MACIESZA STEFAN UR. 01.01.1906 † 18.09.1939 ZAMIANY, STRZEL. MACIORA WŁADYSŁAW UR. 1912 † 19.09.1939 NAROL, STRZEL. MADRZYK STANISŁAW UR. 1916 † 19.09.1939 BEŁŻEC, STRZEL. MALCZYK JULIAN UR. 1911 † 04.10.1939 BIŁGORAJ, MALCZEWSKI ALFRED † 1939 ZAMOŚĆ, STRZEL. MAŃCZYK ERYK † 19.09.1939 BEŁŻEC

ST. SIERŻ. KORZEŃSKI ROMAN † 15.09.1939 BIŁGORAJ, PPOR. KOŚCIŃSKI JAN-ANTONI UR. 09.01.1912 † 18.09.1939 LIPSKO, ST. STRZEL. KOWALSKI JÓ- 
ZEF † 18.09.1939 LIPSKO, ST. STRZEL. KOWALSKI SZYMON † 09.1939 RACHANIE, STRZEL. KOWALSKI WALENTY UR. 1902 † 20.09.1939 BIŁGORAJ, STRZEL. KOZIOŁ WŁADYSŁAW UR. 1913 † 18.09.1939 MAZIŁY, BOMB. KRALKA LUCJAN † 19.09.1939 ZAMIANY, STRZEL. KRASKA JÓZEF UR. 1899 † 18.09.1939 ZWIERZYNIEC, STRZEL. KRAWCZYK STANISŁAW † 19.09.1939 ZAMOŚĆ, STRZEL. KROTLA JAN † 18.09.1939 ZWIERZYNIEC, ST. STRZEL. KRZAKAŁO ALOJZY UR. 1915 † 18.09.1939 MAZIŁY, POR. KUCHNIK WŁADYSŁAW FR. UR. 26.10.1910 † 19.09.1939 LIPSKO, STRZEL. KUFCZAK WŁADYSŁAW † 18.09.1939 LASOCHY, STRZEL. KULAK FRANCISZEK UR. 1906 † 18.09.1939 MAZIŁY, ST. STRZEL. KULIKOWSKI MARIAN † 20.09.1939 MAJDAN GÓRNY, STRZEL. KULIM MONCHAJT † 20.09. 1939 ZAMIANY

STRZEL. DEMKIW ANDRZEJ † 19.09.1939 ULÓW, ST. STRZEL. DOCZYŃSKI KAZIMIERZ † 18.09.1939 ULÓW, STRZEL. DOROBA WACŁAW † 18.09.1939 ULÓW, STRZEL. DOSTYCH HENRYK † 09.1939 HRUBIESZÓW, STRZEL. DUCHOLA M. † 18.09.1939 PAARY, ST. STRZEL. DUDELA ALEKSANDER † 18.09.1939 PAARY, STRZEL. DUŻNIAK STEFAN † 18.09.1939 ULÓW, STRZEL. DYBAŁ JÓZEF † 18.09.1939 PAARY, STRZEL. DZIKI KAROL † 18.09.1939 MAJDAN SOPOCKI, PPOR. DZIUBEK ZBIGNIEW MICHAŁ UR. 1916 † 18.09.1939 PAARY, KPR. DŻYGAŁO JÓZEF † 1944, ST. STRZEL. FABISZEWSKI BOLESŁAW † 18.09.1939 PAARY, STRZEL. FALKUS JÓZEF † 18.09.1939 ULÓW, STRZEL. FANSCH MAKS † 23.09.1939 TARNAWATKA, KPR. FILIPEK PIOTR † 23.09.1939 NEDEŻÓW, STRZEL. FROSZTEGA STANISŁAW † 18.09.1939 PAARY

ST. STRZEL. GABRYŚ STANISŁAW † 18.09.1939 ULÓW, ST. STRZEL. GADZIŃSKI SZCZEPAN UR. 1899 † 19.09.1939 ULÓW, STRZEL. GAŁĄZKA JÓZEF † 19.09.1939 ULÓW, STRZEL. GAWRON EDWARD † 19.09.1939 ULÓW, ST. STRZEL. GIERA PIOTR UR. 14.07.1919 † 19.09.1939 ULÓW, PPOR. GILL WACŁAW LEON UR. 28.09.1909 † 19.09.1939 ULÓW, STRZEL. GŁADYSZ STANISŁAW UR. 1912 † 19.09.1939 TARNAWATKA, STRZEL. GODUŁA FRANCISZEK † 18.09.1939 PAARY, SIERŻ. GOLA † 19.09.1939 ULÓW, STRZEL. GOŁYSZNY BOLESŁAW UR. 2.09.1912 † 18.09.1939 ULÓW, STRZEL. GORGUREWICZ KAROL UR. 1903 † 18.09.1939 ULÓW, PLUT. GRABIŃSKI ALOJZY † 18.09.1939 ZIELONE, PLUT. GRABOWSKI STANISŁAW † 23.09.1939 TARNAWATKA, KPR. GRABSKI ANDRZEJ † 23.09.1939 TARNAWATKA, KAN. GREIFT EWALD UR. 17.05.1916 † 23.09.1939 NEDEŻÓW, PLUT. GRUCA JAN † 23.09.1939 TARNAWATKA

STRZEL. GASIK WACAŁW † 22.09.1939 PODHUCIE, PLUT. GAWLIKOWSKI JERZY † 24.09.1939 PODHUCIE, STRZEL. GAWLIKOWSKI STANISŁAW UR. 1914 † 24.09.1939 PODHUCIE, ST. STRZEL. GÓRKA KAZIMIERZ † 23.09.1939 PODHUCIE, KPR. GÓRSZCZYK JÓZEF † 20.09.1939 MAJDAN WIELKI, STRZEL. GROBCZAK ANTONI † 22.09.1939 PODHUCIE, [...] $]^{61}$ GRUDZIEŃ PIOTR † 1939 ZAMOŚĆ, STRZEL. GRZESIU BOLESŁAW † 1939 ZAMOŚĆ, PLUT. HAJDUKIEWICZ KAZIMIERZ UR. 3.02.1914 † 20.09.1939 MAJDAN WIELKI, PPOR. JABŁOŃSKI JAN STANISŁAW UR. 22.11.1904 † 18.09.1939 PAARY, KPR. JABŁOŃSKI WACŁAW † 22.09.1939 PODHUCIE, KPR. JĘDRZEJEWSKI FRANCISZEK UR. 1916 † 23.09.1939 PODHUCIE, ST. STRZEL. JUREWICZ JAN s. MARIANA UR. 1916 † 23.09.1939 PODHUCIE, STRZEL. KACZMAŃSKI † 20.09.1939 MAJDAN WIELKI, STRZEL. KACZOR FELIKS † 24.09.1939 PODHUCIE, STRZEL. KAMIONKA LUDWIK † 23.09.1939 PODHUCIE

KPR. KAROLAK JÓZEF † 23.09.1939 MAJDAN WIELKI, KICIŃSKI EDWARD † 1939 ZAMOŚĆ, KICIŃSKI TADEUSZ † 1939 ZAMOŚĆ, POR. KLUS PAWEŁ UR.

$\overline{61}$ Na tablicy pozostawiono wolne miejsce. 
31.12.1908 † 23.09.1939 PODHUCIE, SZWOL[EŻER] KOHN GUNTER † 20.09.1939 MAJDAN WIELKI, STRZEL. KONIECZNY BOHDAN † 23.09.1939 TARNAWATKA, KAN. KONTRATIUK NIKADY UR. 1917 † 24.09.1939 PODHUCIE, STRZEL. KOROLEWICZ JÓZEF † 18.09.1939 MAJDAN WIELKI, STRZEL. KOSTAREK MARCIN UR. 14.06.1915 † 20.09.1939 MAJDAN WIELKI, KPR. KOWAL BRUNON † 20.09.1939 MAJDAN WIELKI, ST. STRZEL. KOWALCZYK MICHAŁ † 22.09.1939 PODHUCIE, STRZEL. KOWALSKI ANDRZEJ † 20.09.1939 MAJDAN WIELKI, ST. STRZEL. KOZIOŁ ALEKSY † 23.09.1939 PODHUCIE, PLUT. LAKS MONIAK † 19.09.1939 MAJDAN WIELKI, ST. STRZEL. LISOWER JAN † 23.09.1939 PODHUCIE, KPR. ŁAPIŃSKI JÓZEF † 23.09.1939 PODHUCIE

STRZEL. ŁASEK FRANCISZEK † 19.09.1939 MAJDAN WIELKI, STRZEL. ŁATA WOJCIECH † 23.09.1939 PODHUCIE, STRZEL. MADRIN † 23.09.1939 PODHUCIE, KAN. MAGOŃ KAROLUR. 1914 † 20.09.1939 MAJDAN WIELKI, STRZEL. MAJEWSKI MIECZYSŁAW † 18.09.1939 LIPSKO, MARZEC ADAM † 1939 ZAMOŚĆ, KPR. PCHOR. MARZEC JAN UR. 13.10.1919 † 23.09.1939 PODHUCIE, ST. SZER. MATYSIAK STEFAN UR. 15.04.1915 † 20.09.1939 MAJDAN WIELKI, STRZEL. MERCHEL JÓZEF UR. 11.11.1911 † 20.09.1939 MAJDAN WIELKI, PPOR. MOCZULSKI STANISŁAW UR. 10.02.1909 † 23.09.1939 PODHUCIE, STRZEL. MOZEL WIKTOR † 23.09.1939 PODHUCIE, BOMB. MUCHA JAN s. JAKUBA UR. 19.10.1913 † 20.09.1939 MAJDAN WIELKI, ST. STRZEL. NIEWIADOMSKI FRANCISZEK † 23.09.1939 PODHUCIE, NAKLICKI WIKTOR † 1939 ZAMOŚĆ, STRZEL. NOWAK JAN † 23.09.1939 PODHUCIE, STRZEL. NOWAKOWSKI JERZY † 23.09.1939 PODHUCIE

KPR. PCHOR. OSIECKI ZDZISŁAW † 23.09.1939 PODHUCIE, STRZEL. OSUCHOWSKI STANISŁAW † 20.09.1939 MAJDAN WIELKI, PACHŁO WACŁAW † 1939 ZAMOŚĆ, STRZEL. PARTYKUS JAN † 22.09.1939 PODHUCIE, STRZEL. PASTAK ROMAN † 23.09.1939 PODHUCIE, STRZEL. PASTECZNIK JAN UR. 19.09.1917 † 23.09.1939 PODHUCIE, ST. STRZEL. PAWELEC JAN UR. 1913 † 23.09.1939 PODHUCIE, PIRÓG WŁADYSŁAW † 1939 ZAMOŚĆ, STRZEL. PODSIADŁY STANISŁAW UR. 1913 † 24.09.1939 PODHUCIE, STRZEL. PTASIŃSKI JAN † 24.09.1939 PODHUCIE, PPOR. RADWAŃSKI TADEUSZ FELIKS UR. 18.05.1909 † 23.09.1939 PODHUCIE, SZWOL. REJMANIAK JÓZEF UR. 23.02.1902 †20.09.1939 MAJDAN WIELKI, KPT. RÓŻAŃSKI JÓZEF UR. 10.03.1893 † 22.09.1939 PODHUCIE, RTM. RUDZIŃSKI STANISŁAW JERZY UR. 25.04.1895 † 23.09.1939 PODHUCIE, STRZEL. RYBAK JÓZEF UR. 1917 † 24.09.1939 PODHUCIE, STRZEL. SIKORA IRENEUSZ † 18.09.1939 PAARY

KPR. SITARZ JAN † 21.09.1939 ZIELONE, STRZEL. SIWY JANUSZ UR. 1912 † 24.09.1939 PODHUCIE, STRZEL. SKOMUDEK JÓZEF UR. 10.05.1909 † 20.09.1939 MAJDAN WIELKI, STRZEL. SŁABIK IGNACY UR. 1913 † 20.09.1939 MAJDAN WIELKI, STRZEL. SMOLIK JÓZEF † 23.09.1939 PODHUCIE, KPR. SOBCZAK WOJCIECH † 24.09.1939 PODHUCIE, KPR. SONNECK MAKSYMILIAN UR. 1918 † 20.09.1939 MAJDAN WIELKI, STRZEL. SÓWKA EDWARD FRANCISZEK † 23.09.1939 PODHUCIE, STRZEL. SUFRYD STANISŁAW + 24.09.1939 PODHUCIE, SURMACZ WŁADYSŁAW † 1939 ZAMOŚĆ, SUWAŁKA JÓZEF † 1939 ZAMOŚĆ, STRZEL. SWOŻBA PAWEŁ JAN UR. 23.12.1914 † 20.09.1939 MAJDAN WIELKI, SZARY TADEUSZ † 1939 ZAMOŚĆ, MŁ[ODSZY] JUN[AK] SZAFRAN KAROL s. JANA UR. 5.11.1919 † 23.09.1939 MAJDAN WIELKI, STRZEL. SZEMIS BRONISŁAW † 23.09.1939 PODHUCIE, STRZEL. SZEMERDA FRANCISZEK † 20.09.1939 MAJDAN WIELKI

STRZEL. SZMIDKA FRANCISZEK JAN UR. 1909 † 20.09.1939 MAJDAN WIELKI, STRZEL. ŚCIBOR JÓZEF UR. 14.04.1915 † 20.09.1939 MAJDAN WIELKI, STRZEL. ŚLE- 
SICKI CZESŁAW UR. 12.11.1919 † 20.09.1939 MAJDAN WIELKI, KPR. SLĘZAK JAN † 23.09.1939 PODHUCIE, STRZEL. UTRATA RUFIN s. JANA UR. 25.09.1939† 20.09.1939 MAJDAN WIELKI, KPR. WERBLICKI JAN † 23.09.1939 PODHUCIE, WĘCŁAWIK WACŁAW † 1939 ZAMOŚĆ, ST. STRZEL. WOJNACKI STANISŁAW † 22.09.1939 PODHUCIE, ST. STRZEL. WOJNARSKI MIKOŁAJ UR. 31.08.1915 † 23.09.1939 PODHUCIE, STRZEL. WOŹNIAK ANTONI † 23.09.1939 PODHUCIE, ST. STRZEL. ZŁOTNICKI TADEUSZ † 23.09.1939 PODHUCIE, STRZEL. ZNOSTEK JAN † 23.09.1939 PODHUCIE, KPR. ZYSK FRANCISZEK UR. 27.05.1912 † 20.09.1939 MAJDAN WIELKI, ŻOŁNACZ BRONISŁAW † 1939 ZAMOŚĆ

BOMB. GRUSZKA TADEUSZ † 18.09.1939 ZIELONE, PLUT. GRZEGALSKI † 18.09.1939 ZIELONE, KAN. GRZYBEK T. † 19.09.1939 PAŃKÓW, KAN. GRZYBER IGNACY † 19.09.1939 ZIELONE, KPR. GRZYBOWSKI EDWARD UR. 1912 † 23.09.1939 TARNAWATKA, GUZOWSKI ZYGMUNT † 1944 RZECZYCA, HAŁAS MIECZYSŁAW † 1944 LASY POSADOWSKIE, STRZEL. HAŁDA JÓZEF UR. 1917 † 18.09.1939 MAJDAN SOPOCKI, POR. HERMAN MARIAN STANISŁAW UR. 2.02.1909 † 18.09.1939 ULÓW, STRZEL. HOŁODZIC HENRYK † 18.09.1939 MAJDAN SOPOCKI, KPR. HORODEYCZUK ADAM † 20.09.1939 ULÓW, STRZEL. INBEL WŁADYSŁAW † 18.09.1939 PAARY, STRZEL. INIOLCZYK RYSZARD † 18.09.1939 ULÓW, STRZEL. JAESCHKE ANTONI † 23.09.1939 TARNAWATKA, STRZEL. JAKUB... ${ }^{62}$ JAN UR. $1914+19.09 .1939$ MAJDAN SOPOCKI, PARTYZANT JANIK CZESŁAW † 1944

STRZEL. JANKOWSKI MICHAŁ † 18.09.1939 PAARY, PPOR. JANKOWSKI TADEUSZ UR. 28.03.1914 † 18.09.1939 ZIELONE, KPR. JASIŃSKI ALEKSANDER UR. 1914 † 19.09.1939 MAJDAN SOPOCKI, JASTRZĘBSKI JAN † 1944, STRZEL. JEMIOŁO ALEKSANDER UR. 16.07.1916 † 18.09.1939 ULÓW, STRZEL. JURA WŁADYSŁAW † 18.09.1939 MAJDAN SOPOCKI, STRZEL. JURECZKO WILHELM † 18.09.1939 ZIELONE, JURKIEWICZ MIECZYSŁAW † 1944 LASY POSADOWSKIE, STRZEL. KADYJ BRONISŁAW UR. 1889 † 20.09.1939 ZIELONE, STRZEL. KAŃCZUKA PAWEŁ † 18.09.1939 ZIELONE, PPOR. KAŃSKI EUGENIUSZ UR. 27.09.1911 † 19.09.1939 ULÓW, KARWAN PAWEŁ † 1944 LASY POSADOWSKIE, STRZEL. KASPRZAK JAN † 19.09.1939 ZIELONE, PPŁK KASZTELANOWICZ JAN UR. 10.12.1896 † 23.09.1939 TARNAWATKA, KPR. KENDZIORA WŁADYSŁAW UR. 2.03.1906 † 19.09.1939 ULÓW, ST. STRZEL. KIRTA JÓZEF † 18.09.1939 ULÓW

STRZEL. KIRZEŃ FLORIAN † 18.09.1939, KPR. KNAPIK FRANCISZEK † 18.09.1939 PAARY, STRZEL. KLUGER DAWID UR. 16.09.1914 † 18.09.1939 ULÓW, STRZEL. KOŁACZ FRANCISZEK † 18.09.1939 PAARY, STRZEL. KONARSKI WIKTOR † 18.09.1939 ULÓW, STRZEL. KONOBA (KUDYBA) ANTONI † 23.09.1939 NOWA WIEŚ, KAN. KOPCZARSKI (KUPCZEWSKI) † 19.09.1939 ULÓW, STRZEL. KOPEĆ JÓZEF † 18.09.1939 PAARY, KOPEĆ TADEUSZ † 1944 LASY POSADOWSKIE, STRZEL. KOPEĆ ZYGMUNT † 18.09.1939 PAARY, STRZEL. KORZEN FLORIAN † 19.09.1939 PAARY, PPOR. KORZYBSKI ZDZISŁAW ANTONI UR. 18.12.1915 † 18.09.1939 SZAROWOLA, STRZEL. KOSTAREK JULIAN † 19.09.1939 ULÓW, ST. STRZEL. KOSTKA PAWEŁ † 18.09.1939 PAARY, STRZEL. KOSZYK ZDZISŁAW † 23.09.1939 TARNAWATKA, PLUT. KOWALONEK MICHAŁ † 23.09.1939 TARNAWATKA

STRZEL. KOWALSKI ANTONI UR. 21.02.1910 † 19.09.1939 ZIELONE, STRZEL. KOWALSKI STEFAN † 19.09.1939 ULÓW, PPOR. KOWALSKI TADEUSZ KAZIMIERZ

${ }^{62}$ Nazwisko niedokończone. 
UR. 30.10.1901 † 19.09.1939 ULÓW, ST. STRZEL. KOZIOŁ JÓZEF UR. 20.01.1904 † 19.09.1939 ULÓW, ST. STRZEL. KRALKA JULIAN UR. 1915 † 18.09.1939 SZAROWOLA, PLUT. KRAJEWSKI J. † 23.09.1939 TARNAWATKA, KAN. KROMER WŁADYSŁAW UR. 1912 † 23.09.1939 NEDEŻÓW, STRZEL. KRUCZYŃSKI KAZIMIERZ † 23.09.1939 TARNAWATKA, ST. STRZEL. KRUKOWSKI JAN † 19.09.1939 ULÓW, STRZEL. KRYWCZUK ELIASZ † 19.09.1939 ULÓW, ST. UŁAN KRZYŻOWSKI STEFAN † 19.09.1939 ULÓW, STRZEL. KSIĄŻEK JÓZEF † 18.09.1939 PAARY, STRZEL. KUBAS ALOJZY † 18.09.1939 ULÓW, STRZEL. KUCZKOWSKI MARIAN † 09.1939 HRUBIESZÓW, STRZEL. KUCZKOWSKI OLGIERD JAN, UR. 18.06.1916 † 19.09.1939 ULÓW, KPR. KUFA JAN † 19.09.1939 ULÓW

ST. STRZEL. KULBIŃSKI WŁADYSŁAW UR. 1916 † 19.09.1939 MAJDAN SOPOCKI, STRZEL. KULIBOWSKI HENRYK † 19.09.1939 ULÓW, STRZEL. KUNC IGNACY † 14.09.1939 HRUBIESZÓW, PPOR. KUNCE RUDOLF FELIKS UR. 20.11.1907 † 18.09.1939 PAARY, STRZEL. KURA JÓZEF † 18.09.1939 ULÓW, KURZĘPA HIPOLIT † 1944, STRZEL. KUTEL ALFONS † 25.09.1939 TARNAWATKA, STRZEL. KUŹNIK DYMITR † 19.09.1939 HRUBIESZÓW, LALKA WŁADYSŁAW † 18.09.1939 ULÓW, PPOR. LEBEK MACIEJ UR. 24.02.1916 † 19.09.1939 ULÓW, STRZEL. LEONOWICZ PIOTR † 18.09.1939 PAARY, STRZEL. LESOCZYK KAROL † 19.09.1939 ULÓW, STRZEL. LEŚNIK MOJSIEJ † 18.09.1939 ULÓW, ST. STRZEL. LEWANDOWSKI WACŁAW † 23.09.1939 TARNAWATKA, STRZEL. LEWAROWICZ JAN † 18.09.1939 PAARY, PPOR. LIGENZA ZYGMUNT IGNACY UR. 1.02.1913 † 19.09.1939 ULÓW

STRZEL. MATLA KONRAD † 19.09.1939 ZWIERZYNIEC, STRZEL. MATUSZEK EMIL † 18.09.1939 MAZIŁY, STRZEL. MICHALAK ADOLF † 23.09.1939 ANTONIÓWKA, STRZEL. MICHALAK IGNACY-PIOTR † 19.09.1939 ZAMIANY, STRZEL. MICHALSKI W. † 21.09.1939 LIPSKO, STRZEL. MIERZYŃSKI MARIAN † 23.09.1939 PODLODÓW, STRZEL. MIKA WACŁAW † 19.09.1939 BEŁŻEC, STRZEL. MIKOŁAJCZYK MIKOŁAJ † 18.09.1939 MAZIŁY, STRZEL. MIKULSKI MIECZYSŁAW UR. 18.12.1916 † 20.09.1939 ZAMIANY, POR. MIRAKOWSKI HENRYK UR. 27.11.1897 † 23.09.1939 PODLODÓW, STRZEL. MUCHA † 23.09.1939 NOWA WIEŚ, STRZEL. MUCHA † 20.09.1939 MAJDAN GÓRNY, STRZEL. MUSIAŁ ALOJZY UR. 1916 † 20.09.1939 BIŁGORAJ, STRZEL. MYŚLIWIEC WILHELM † 19.09.1939 ZAMOŚĆ, STRZEL. MYŚLIWY ANTONI † 18.09.1939 MAZIŁY, STRZEL. NANKIER KAROL † 18.09.1939 BIAŁY SŁUP

SZER. NAPORZEWSKI MARIAN † 23.09.1939 BIŁGORAJ, SZER. NAUKIR KAROL † 18.09.1939 BIŁGORAJ, POR. NIEWIADOLSKI WITOLD-ALEKS UR. 30.04.1911 † 20.09.1939 LIPSKO, STRZEL. NOWACKI † 20.09.1939 MAJDAN GÓRNY, STRZEL. NOWACZEK WŁADYSŁAW † 23.09.1939 RACHANIE, STRZEL. NOWAK † 19.09.1939 ZAMOŚĆ, STRZEL. NOWAK JÓZEF † 23.09.1939 PRZEWŁOKA, STRZEL. OBIEŻAŁEK ALEKSANDER † 23.09.1939 MAJDAN GÓRNY, STRZEL. OCHMAN FRANCISZEK † 15.09.1939 BIŁGORAJ, STRZEL. OKSADNIK WIKTOR UR. 1914 † 24.09.1939 BIŁGORAJ, KPR. OLESZCZYŃSKI FELIKS † 23.09.1939 PODLODÓW, STRZEL. OLKUSZ ONUCA † 23.09.1939 RACHANIE, ST. STRZEL. OSIKA STANISŁAW † 20.09.1939 ZAMIANY, PPOR. PAPUSZKA ZBIGNIEW UR. 1917 † 18.09.1939 ZAMOŚĆ, PPOR. PASTERNAK WIKTOR UR. 28.10.1912 † 18.09.1939 ZAMOŚĆ, STRZEL. PATURA STANISŁAW † 23.09.1939 PODLODÓW

ST. STRZEL. PAWLIKOWSKI STANISŁAW † 20.09.1939 MAJDAN GÓRNY, STRZEL. PECAK ANTONI UR. 24.05.1921 † 19.09.1939 BEŁŻEC, STRZEL. PETROLUK DY- 
MITR † 20.09.1939 MAJDAN GÓRNY, STRZEL. PĘDZICH WŁADYSŁAW UR. 1910 † 01.10.1939 BIŁGORAJ, STRZEL. PĘDZIWIATR ALFRED UR. 18.06.1912 † 19.09.1939 LIPSKO, PLUT. PILC ANTONI † 22.09.1939 NIEWIARKÓW, PPOR. PIOTROWSKI ANDRZEJ UR. 19.01.1907 † 18.09.1939 ZWIERZYNIEC, CHOR. PISAREK KONSTANTY † 18.09.1939 LASOCHY, STRZEL. PIWOWAR WŁADYSŁAW UR. 5.11.1908 † 21.09.1939 BIŁGORAJ, PPOR. PIWOWARCZYK BOGUSŁAW UR. 10.02.1911 † 20.09.1939 NAROL, PLUTA EUGENIUSZ UR. 1913 †18.09.1939 MAZIŁY, STRZEL. PŁASZEWSKI EDWARD † 18.09.1939 ZWIERZYNIEC, PODCH. POGONOWSKI ANDRZEJ † 19.09.1939 ZWIERZYNIEC, PLUT. POLAK JAN † 23.09.1939 ZWIERZYNIEC, STRZEL. POLAK STANISŁAW † 18.09.1939 LIPSKO, KPR. POPIELARCZYK STANISŁAW † 19.09.1939 BEŁŻEC

STRZEL. POPOWICZ BAZYLI † 15.09.1939 BIŁGORAJ, STRZEL. POŹNIAK STEFAN † 22.09.1939 PODHORCE, POR. PREIZNER JÓZEF EUGENIUSZ UR. 1911 † 18.09.1939 MAZIŁY, STRZEL. PRACZYK STANISŁAW UR. 1909 † 23.09.1939 PRZEWŁOKA, STRZEL. PROSTEGA STANISŁAW † 18.09.1939 NAROL, SZER. PRUSKI JAN † 18.09.1939 ZWIERZYNIEC, STRZEL. PRZYBYŁA JAN † 18.09.1939 ZWIERZYNIEC, STRZEL. PSZCZÓŁOWSKI W. † 22.09.1939 MAJDAN GÓRNY, STRZEL. PTAK BOLESŁAW † 18.09.1939 ZWIERZYNIEC, STRZEL. PUDŁO JÓZEF + 18.09.1939 MAZIŁY, POR. PUZYNA EDMUND UR. 12.07.1909 + 19.09.1939 BEŁŻEC, STRZEL. PYPŁACZ LEON † 19.09.1939 ŁUSZCZACZ, STRZEL. PYPNO WŁADYSŁAW † 18.09.1939 BIAŁY SŁUP, STRZEL. RADWAŃSKI JAN † 18.09.1939 MAZIŁY, KPR. RITTER WILHELM † 20.09.1939 ZAMIANY, STRZEL. ROKOWSKI JAN † 19.09.1939 NAROL

STRZEL. MATULA JAN † 18.09.1939 MAJDAN SOPOCKI, STRZEL. MAZUR JÓZEF † 18.09.1939 ULÓW, KPR. MICHALCZUK ALEKSANDER UR. 26.06.1906 † 19.09.1939 ULÓW, PPOR. MIKOSZEWSKI ANTONI UR. 8.10.1909 † 19.09.1939 ULÓW, MILLER BOGDAN † 1944, PPOR. MISKA MIECZYSŁAW UR. 1912 † 19.09.1939 PAŃKÓW, STRZEL. MŁYNARCZYK JAN † 15.09.1939 HRUBIESZÓW, MOMOT ZYGMUNT † 1944 LASY POSADOWSKIE, STRZEL. MORAWSKI MARCIN † 18.09.1939 ULÓW, STRZEL. MOTEK † 18.09.1939 ULÓW, PPOR. MROWIEC KAROL MIECZYSŁAW UR. 6.01.1912 † 19.09.1939 MAJDAN SOPOCKI, STRZEL. MUCHA JAN UR. 4.05.1912, † 19.09.1939 PAŃKÓW, ST. STRZEL. MUSIAŁ FRANCISZEK † 19.09.1939 ULÓW, KPR. MUSZYŃSKI JÓZEF UR. 1914 † 23.09.1939 TARNAWATKA, KPT. MYTKOWICZ MARIAN JAN, UR. 8.12.1906 † 19.09.1939 ZIELONE, STRZEL. NAPIERAŁA ANTONI UR. 1916 † 19.09.1939 MAJDAN SOPOCKI

STRZEL. NAPOLEWSKI MARIAN † 23.09.1939 TARNAWATKA, NAWROCKI STANISŁAW † 1944, STRZEL. NEYSAREK KAZIMIERZ † 18.09.1939 ULÓW, NIEŚCIOR JAN, LASY POSADOWSKIE, STRZEL. NIKLAS ZYGFRYD UR. 1918 † 23.09.1939 NEDEŻÓW, KPR. NOIŃSKI JERZY † 02.06.1944 RZYCZYCA, SZER. NOWAK STANISŁAW † 20.09.1939 ZIELONE, STRZEL. NOWAK WALENTY UR. 1916 † 19.09.1939 MAJDAN SOPOCKI, STRZEL. OCHMAŃSKI JÓZEF † 18.09.1939 PAARY, STRZEL. OLEKSIEWICZ JÓZEF † 18.09.1939 PAARY, ST. STRZEL. OLEKSY JAN † 18.09.1939 PAARY, STRZEL. OSIŃSKI ZYGMUNT † 18.09.1939 PAARY, STRZEL. PANEK IGNACY UR. 6.05.1902 † 23.09.1939 TARNAWATKA, STRZEL. PARADIUK MICHAŁ † 18.09.1939 PAARY, STRZEL. PIECHA JAN UR. 1912 † 18.09.1939 ZIELONE, STRZEL. PIEKARCZYK STANISŁAW + 23.09.1939 TARNAWATKA

STRZEL. PIETRAKIEWICZ WINCENTY † 18.09.1939 PAARY, STRZEL. PLAPLA ABRAHAM † 18.09.1939 ULÓW, STRZEL. POLAKOWSKI ALFONS † 23.09.1939 NEDE- 
ŻÓW, KPR. POGWIZD KAROL † 19.09.1939 ULÓW, STRZEL. PONIEDZIELNIK KIRY七 † 18.09.1939 MAJDAN SOPOCKI, STRZEL. POPIERNIK BRONISŁAW † 18.09.1939 PAARY, ST. STRZEL. POPOLAN FRANCISZEK UR. 1910 † 19.09.1939 MAJDAN SOPOCKI, STRZEL. POŚPIECH LUDWIK † 18.09.1939 ULÓW, STRZEL. PRZYBYCIN JÓZEF UR. 1902 † 18.09.1939 ZIELONE, STRZEL. PRZYKLĘK KAZIMIERZ † 18.09.1939 ULÓW, STRZEL. PSZCZÓŁKA JÓZEF † 18.09.1939 ULÓW, PUCHACZ ADOLF † 1944, STRZEL. RADLIN ADOLF † 19.09.1939 ULÓW, STRZEL. RADOŃ PIOTR † 19.09.1939 ZIELONE, PPOR. RASZKA KURT †19.09.1939 ULÓW, KPR. ROGOWSKI STEFAN UR. 17.06.1917 †18.09.1939 ZIELONE

STRZEL. JAŃCZUK PIOTR UR. 1917 † 20.09.1939 ZAMIANY, STRZEL. JARZĄBEK WŁADYSŁAW † 19.09.1939 BEŁŻEC, STRZEL. JASIŃSKI WŁADYSŁAW † 15.09.1939 BIŁGORAJ, STRZEL. JAŚKO JÓZEF UR. 1918† 18.09.1939 ZWIERZYNIEC, KPR. JEDLICZKA JERZY † 19.09.1939 BEŁŻEC, STRZEL. JĘDRYSIK LEON UR. 1913 † 03.10.1939 BIŁGORAJ, STRZEL. JĘDRZEJEWSKI LEOPOLD UR. 18.06.1911 † 19.09.1939 BEŁŻEC, STRZEL. JÓŹWIK JAN † 19.09.1939 ANTONIÓWKA, STRZEL. JURCZAK WINCENTY † 19.09.1939 ŁASOCHY, PLUT. JUSZCZYK JAN UR. 1920 † 18.09.1939 ZAMOŚĆ, STRZEL. KACZMARCZYK ADOLF † 26.09.1939 BIŁGORAJ, PLUT. KAŁUŻNY BOLESŁAW † 18.09.1939 ZWIERZYNIEC, KPR. KAMDA EDWARD † 03.10.1939 BIŁGORAJ, KPR. KAMELA EDWARD † 03.10.1939 BIŁGORAJ, STRZEL. KARBOWNIK PIOTR UR. 1916 † 20.09.1939 ZAMIANY, PPOR. KARNOWSKI WITOLD UR. 09.04.1909 † 18.09.1939 ZWIERZYNIEC

PLUT. LIPIACH † 20.09.1939 ZIELONE, PPOR. LISOWSKI WŁODZIMIERZ UR. 23.01.1907 † 19.09.1939 ULÓW, PCHOR. LITWIN WITOLD † 18.09.1939 ZIELONE, STRZEL. LONTEK JULIAN † 19.09.1939 ZIELONE, ST. STRZEL. LUBASZEWSKI ZYGMUNT † 18.09.1939 MAJDAN SOPOCKI, STRZEL. ŁABNO FRANCISZEK UR. 7.08.1914 † 17.09.1939 MAJDAN SOPOCKI, KPR. ŁAGOCKI JAN UR. 1906 † 23.09.1939 TARNAWATKA, STRZEL. ŁAKOMA JÓZEF † 17.09.1939 MAJDAN SOPOCKI, ST. STRZEL. ŁUKASIEWICZ JAN † 23.09.1939 TARNAWATKA, KPT. ŁYSZCZARZ MARCIN UR. 19.09.1906 † 18.09.1939 ULÓW, STRZEL. ŁYŻBICKI PAWEŁ † 19.09.1939 ULÓW, STRZEL. MACELUCH JÓZEF UR. 1917 † 19.09.1939 MAJDAN SOPOCKI, ST. STRZEL. MAKUŁA JÓZEF UR. 1912 † 09.10.1939 HRUBIESZÓW, KPR. MALBORCZYK WŁADYSŁAW † 19.09.1939 ZIELONE, KAN. MANHEIM † 19.09.1939 ZIELONE, STRZEL. MARIOWSKI PAWEŁ UR. $1915+$ 18.09.1939 ULÓW

STRZEL. ROKICKI JAN † 23.09.1939 NEDEŻÓW, STRZEL. ROLA JAN † 18.09.1939 ZIELONE, STRZEL. ROMANOWICZ ANTONI UR. 1913 † 19.09.1939 TARNAWATKA, UŁAN ROMANOWSKI LUDWIK † 13.09.1939 PAŃKÓW, STRZEL. ROZMUS WŁADYSŁAW † 18.09.1939 ULÓW, POR. RUDZIŃSKI ZBIGNIEW † 18.09.1939 ZIELONE, KPR. RUTKOWSKI JAN † 18.09.1939 PAARY, RYCHTER † 20.09.1939 ZIELONE, STRZEL. RYSZKA MICHAŁ † 19.09.1939 ULÓW, ST. STRZEL. RZEPECKI JÓZEF † 23.09.1939 TARNAWATKA, STRZEL. SAKOWSKI TADEUSZ † 19.09.1939 MAJDAN SOPOCKI, KPR. SAPETA STEFAN † 19.09.1939 MAJDAN SOPOCKI, PLUT. PCHOR. SAPLIC KAZIMIERZ UR. 11.11.1915 † 23.09.1939 TARNAWATKA, STRZEL. SAZIORA FELIKS † 23.09.1939 TARNAWATKA, STRZEL. SIMKA PAWEŁ † 19.09.1939 ULÓW, MJR SKOCZYLAS SZYMON UR. 27.10.1894 † 18.09.1939 PAARY

STRZEL. ROMIK STANISŁAW † 18.09.1939 ZWIERZYNIEC, STRZEL. ROSIAK TOMASZ † 22.09.1939 MAJDAN GÓRNY, SZER. ROWICKI KLEMENS † 06.10.1939 POD- 
LODÓW, ST. STRZEL. RYNKIEWICZ IGNACY † 23.09.1939 MAJDAN GÓRNY, PPOR. RZĄDKIEWICZ STANISŁAW UR. 30.08.1914 † 18.09.1939 ZAMIANY, STRZEL. SEKUŁA JAN † 20.09.1939 ZAMIANY, KPR. SENGER K. † 18.09.1939 ZAMIANY, KPT. SIEMIATYCKI STANISŁAW UR. 15.12.1897 † 19.09.1939 BEŁŻEC, ST. SIERŻ. SIEMEK JÓZEF † 19.09.1939 ZAMIANY, SAP. SIKORSKI ALFONS † 16.09.1939 BIŁGORAJ, STRZEL. SIOPIERNIK BRONISŁAW † 19.09.1939 LIPSKO, STRZEL. SITKO HENRYK UR. 14.08.1915 † 19.09.1939 BEŁŻEC, POR. SKERL ZYGMUNT UR. 24.04.1907 † 17.09.1939 ZWIERZYNIEC, STRZEL. SKORNIK JAN UR. 1913 † 23.09.1939 BIŁGORAJ, KPR. SKOTNICKI MARIAN UR. 1915 † 18.09.1939 ZAMIANY, KPR. PODCH[ORĄŻY] SŁOWIK BRONISŁAW UR. $1917+$ 18.09.1939 MAZIŁY

KPR. PODCH. SMADEJ M. † 23.09.1939 RACHANIE, STRZEL. SINGUR BAZYLI UR. 1916 † 18.09.1939 MAZIŁY, STRZEL. SOBCZYK JAN UR. 30.09.1916 † 18.09.1939 MAZIŁY, STRZEL. SIBIERNIK BRONISŁAW † 19.09.1939 LIPSKO, STRZEL. SOWA JAN † 23.09.1939 WIERSZCZYCE ${ }^{63}$, POR. SPAŁUNY STANISŁAW † 19.09.1939 LIPSKO, STRZEL. SROKA STANISŁAW † 18.09.1939 MAZIŁY, STRZEL. STANKIEWICZ WACŁAW † 23.09.1939 MAJDAN GÓRNY, ST. STRZEL. STAŃCZYC ANATOL UR. 1909 † 23.09.1939 MAJDAN GÓRNY, STRZEL. STAWINOGA STEFAN † 18.09.1939 LIPSKO, STRZEL. STYCHULSKI MICHAŁ UR. 1904 † 22.09.1939 MAJDAN GÓRNY, STRZEL. STEIGER JÓZEF † 23.09.1939 PODLODÓW, STRZEL. SUJECKI WŁADYSŁAW † 23.09.1939 MAJDAN GÓRNY, KPR. SUSEK AUGUSTYN UR. 1914 † 18.09.1939 LIPSKO, POR. SYDOR IGNACY † 23.09.1939 WIERSZCZYCE, STRZEL. ŚLUZAŁEK STEFAN UR. 1910 † 20.09.1939 BIŁGORAJ

STRZEL. ŚMIETANA WILHELM † 18.09.1939 ZWIERZYNIEC, STRZEL. ŚWISTAK STANISŁAW † 18.09.1939 LIPSKO, STRZEL. ŚWIERSZCZYNA ERYK † 18.09.1939 ZWIERZYNIEC, STRZEL. SWĘDZIOŁ TADEUSZ † 18.09.1939 ZWIERZYNIEC, STRZEL. SZANAJCA JÓZEF † 21.09.1939 PŁAZÓW, STRZEL. SZARO ROMAN † 23.09.1939 MAJDAN GÓRNY, KPR. SZUM PAWEŁ UR. 1910 † 18.09.1939 LIPSKO, STRZEL. SZYKUŁA JÓZEF † 19.09.1939 ZAMOŚĆ, STRZEL. TAFEL WOJCIECH UR. 1907 † 18.09.1939 MAZIŁY, STRZEL. TAKELUN WŁADYSŁAW † 23.09.1939 RACHANIE, KPR. TARASIEWICZ PAWEŁ † 18.09.1939 ZAMIANY, POR. TARKOWSKI KAZIMIERZ UR. 25.11.1906 † 19.09.1939 ZAMIANY, STRZEL. TCHOMAS EMIL † 18.09.1939 ZAMIANY, STRZEL. TELEP JAN UR. 1905 † 24.09.1939 BIŁGORAJ, STRZEL. TENESZCZUK STEFAN † 23.09.1939 TARNAWATKA

ST. STRZEL. SKOWROŃSKI JAN † 23.09.1939 TARNAWATKA, SKROBACZ WŁADYSŁAW † 1944, STRZEL. SKRZYPACZEK WŁADYSŁAW † 18.09.1939 ULÓW, STRZEL. SKRZYPACZYK WILHELM † 19.09.1939 ULÓW, SKURCZ MICHAŁ † 1944, STRZEL. SMAZA ANDRZEJ † 19.09.1939 ULÓW, STRZEL. SOBIERAJSKI KONSTANTY † 18.09.1939 ULÓW, STRZEL. SPRUS JÓZEF † 20.09.1939 ZIELONE, STRZEL. STANEK KLEMENS † 17.09.1939 MAJDAN SOPOCKI, STRZEL. STECZŃ JAN † 18.09.1939 MAJDAN SOPOCKI, STRZEL. STEJBLIS BOLESŁAW † 18.09.1939 ZIELONE, PPOR. STOKOWY ALFRED UR. 30.08.1914 † 19.09.1939 SZARA WOLA, KPT. STRADOMSKI JAN UR. 18.04.1908 † 19.09.1939 PAŃKÓW, STRZEL. STROJEK WŁADYSŁAW † 18.09.1939 ULÓW, STRZEL. STYCHULSKI MICHAŁ UR. 1904 † 22.09.1939 MAJDAN GÓRNY, STRZEL. STYCZEŃ WŁADYSŁAW † 17.09.1939 MAJDAN SOPOCKI

STRZEL. SUCHANEK JÓZEF † 18.09.1939 ULÓW, KPR. PCHOR. SWORZEŃ BOGUMIŁ UR. 22.12.1918 † 17.09.1939 MAJDAN SOPOCKI, SZAJEWSKI JÓZEF † 1944,

${ }^{63}$ Właściwa nazwa miejscowości brzmi: Wierszczyca. 
CHOR. SZARY † 1944, STRZEL. SZCZAKOWA STANISŁAW † 23.09.1939 TARNAWATKA, STRZEL. SZCZERBISKI ROMAN † 19.09.1939 ULÓW, STRZEL. SZKODA KONSTANTY † 19.09.1939 ULÓW, SZMULC JAN † 1944, PPOR. SZUBERT WŁADYSŁAW JÓZEF UR. 10.03.1909 † 18.09.1939 PAARY, KPR. SZUDARSKI CZESŁAW † 23.09.1939 TARNAWATKA, STRZEL. SZWERTER WILHELM LUDWIK UR. 1916 † 23.09.1939 NEDEŻÓW, STRZEL. SZYKUŁA JÓZEF † 19.09.1939 ULÓW, STRZEL. SZYMAŃCZUK EDWARD † 23.09.1939 TARNAWATKA, KPR. SZYMURA METODY UR. 1915 † 19.09.1939 ULÓW, STRZEL. ŚWIST BRONISŁAW † 18.09.1939 PAARY, STRZEL. TENESZCZUK STEFAN † 23.09.1939 TARNAWATKA

STRZEL. THOBOR ERYK † 18.09.1939 PAARY, STRZEL. TKOCZ WILHELM UR. 1914 † 19.09.1939 ULÓW, SAP. TOBISZEWSKI BOLESŁAW † 09.1939 PAARY, KPR. TROJAK JÓZEF † 19.09.1939 MAJDAN SOPOCKI, STRZEL. TWICZYNIEWSKI GRZEGORZ UR. 1912 † 18.09.1939 MAJDAN SOPOCKI, STRZEL. WAGELFNGER DAWID † 29.09.1939 TARNAWATKA, STRZEL. WAJDA ZYGMUNT † 18.09.1939 ZAMOŚĆ, STRZEL. WALCZYŃSKI STANISŁAW † 23.09.1939 PRZEORSK, PPOR. WALEWSKI JAN UR. 14.09.1908 $\dagger$ 19.09.1939 TARNAWATKA, PLUT. WĄSOWICZ WACŁAW † 18.09.1939 ZIELONE, STRZEL. WERNO WALENTY † 23.09.1939 ZIELONE, STRZEL. WĘGRZ... ${ }^{64} \uparrow 19.09 .1939$ PAŃKÓW, STRZEL. WOJTALA TEOFIŁ † 19.09.1939 TARANWATKA, UŁAN WOJTIUK JAROSŁAW † 23.09.1939 TARNAWATKA, UŁAN WOJCIECHOWSKI † 18.09.1939 ZIELONE, ST. STRZEL. WÓJCICKI ALEKSANDER 18.09.1939 PAARY

POR. TOMASZEWSKI BRONISŁAW UR. 02.09.1905 † 18.09.1939 MAZIŁY, STRZEL. TOMASZEWSKI MARIAN UR. 1915 † 22.09.1939 BIŁGORAJ, STRZEL. TRZASKOMA MARIAN † 23.09.1939 PRZEWŁOKA, KPR. TYRKA LUDWIK UR. 1910 † 23.09.1939 ZAMOŚĆ, STRZEL. TYSKA LUDWIK † 21.09.1939 LIPSKO, STRZEL. ULPICH EMANUEL † 18.09.1939 ZWIERZYNIEC, STRZEL. UŁAZOWSKI TADEUSZ † 18.09.1939 ZWIERZYNIEC, STRZEL. WAJDA ZYGMUNT † 20.09.1939 ZAMOŚĆ, PPOR. WALA STANISŁAWA UR. 1916 † 18.09.1939 MAZIŁY, STRZEL. WALICKI IGNACY † 23.09.1939 MAJDAN GÓRNY, STRZEL. WAŁĘGA KAZIMIERZ UR. 1911 † 19.091939 BIŁGORAJ, WAŃCZURA ENRNEST ${ }^{65}+$ 18.09.1939, STRZEL. WARDAK MARCIN † 23.09.1939 PODLODÓW

KPR. WÓJCIK SZYMON UR. 6.10.1911 † 20.09.1939 PAARY, POR. WÓJTOWICZ FRANCISZEK UR. 5.01.1909 † 19.09.1939 MAJDAN SOPOCKI, STRZEL. WRÓBEL JÓZEF UR. 1916 † 23.09.1939 TARNAWATKA, STRZEL. ZAJĄC JÓZEF † 19.09.1939 ULANÓW, STRZEL. ZEGARMISRZ STANISŁAW UR. 1914 † 18.09.1939 ZIELONE, STRZEL. ZAJDEL TADEUSZ † 18.09.1939 PAARY, STRZEL. ZELMAN STANISŁAW † 23.09.1939 TARNAWATKA, STRZEL. ZUBEL WŁADYSŁAW † 09.1939 PAARY, STRZEL. ŻUKOWSKI MARIAN † 09.1939 HRUBIESZÓW, STRZEL. ŻYLEWSKI MIECZYSŁAW † 27.10.1939 HRUBIESZÓW, STRZEL. ŻYWIOŁ FRANCISZEK † 18.09.1939 PAARY

STRZEL. WAXITUCH JÓZEF UR. 09.01.1915 † 21.09.1939 LIPSKO, STRZEL. WĄTROBA STANISŁAW † 20.09.1939 MAJDAN GÓRNY, POR. WIDUCH FRANCISZEK UR. 22.03.1911 + 18.09.1939 ZWIERZYNIEC, STRZEL. WIDYSZ FRANCISZEK † 18.09.1939 BIAŁY SŁUP, STRZEL. WIECZOREK WACŁAW † 23.09.1939 MAJDAN GÓRNY, PPOR. WIELOPOLSKI ALFRED UR. 19.10.1905 † 18.09.1939 ZAMIANY, STRZEL. WIERCIMOK FRANCISZEK UR. 1908 † 09.1939 NAROL, STRZEL. WISZYK ALFRED † 15.09.1939 BIŁGORAJ, STRZEL. WITECKI KAZIMIERZ † 18.09.1939 BIAŁY

\footnotetext{
64 Nazwisko niedokończone.

65 Brzmienie imienia umieszczone na tablicy.
} 
SŁUP, STRZEL. WŁAD JAN UR. 1916 † 20.09.1939 ZAMIANY, PLUT. PCHOR. WOLSKI WŁADYSŁAW † 23.09.1939 RACHANIE, PPOR. WOJTOWICZ TADEUSZ UR. 10.1939 † 23.09.1939 WIERSZCZYCE, STRZEL. WÓJTOWICZ STEFAN UR. 1916 † 19.09.1939 BEŁŻEC, STRZEL. ZACH LEONARD † 18.09.1939 ZWIERZYNIEC, STRZEL. ZARĘBSKI MIECZYSŁAW UR. 14.12.1916 † 18.09.1939 BEŁŻEC, STRZEL. ZASADZIN JÓZEF † 18.09.1939 MAZIŁY

STRZEL. ZAWADA † 19.09.1939 TOMASZÓW LUB[ELSKI], BOMB. ZAWILINSKI WŁADYSŁAW † 20.09.1939 ZAMIANY, STRZEL. ZDECHLIK ROMAN † 18.09.1939 MAZIŁY, KPR. ZIELIŃSKI JAN UR. 1911 † 20.09.1939 ZAMIANY, KPR. ZIEMBA STEFAN † 18.09.1939 MAZIŁY, POR. ZIEMBA ZYGMUNT-MICHAŁ † 18.09.1939 MAZIŁY, STRZEL. ZWOLAKIEWICZ MAKSYM † 18.09.1939 MAZIŁY, PLUT. ŻUPA STEFAN † 22.09.1939 CZEŚNIKI, STRZEL. ŻYTKO ANTONI † 18.09.1939 ZWIERZYNIEC

KAN. GRZYBEK T. † 19.09.1939 PAŃKÓW, PPOR. 5 PSK MISKA MIECZYSŁAW UR. 1912 † 19.09.1939, UŁAN ROMANOWSKI LUDWIK † 13.09.1939, KPT. STRADOMSKI JAN UR. 18.04.1908 † 19.09.1939, WĘGRZ... ${ }^{66}+19.09 .1939$, MUCHA JAN † 19.09.1939, STRZ. 5 PSK MUCHA JAN s. JANA UR. 04.05. 1912 W NIECZAJNIE † 19.09.1939, ŻOŁNIERZ NN † 19.09.1939

\section{TABLICE INDYWIDUALNE}

BRANDT WACŁAW UR. 1907 † 12.09.1939 r., PPOR. BŁASIŃSKI FRANCISZEK † 12.IX.1939, PLUT. PCHOR. PYTEL ADAM UR. 1918 † 09.1939, SANITARIUSZKA TWARDOCH FELICJA ŻYŁA L[AT] 19 † 12.09.1939, SZANAJCA JÓZEF UR. 13.03.1902 † 21.09.1939 POD PŁAZOWEM, RTM. CHODAŃ JAROSŁAW, 5. p.s.k. † 19.09.1939 POD ZAMOŚCIEM, MAZURKIEWICZ HELENA ŻYŁA L[AT] 28 † 1939, PLUT. CHROBAK EDMUND † 18.09.1939

PPOR. PASZYŃSKI HENRYK UR. 06.11.1911 † 23.09.1939 PODHUCIE, RAK TADEUSZ † 1939, WILKIEWICZ JERZY UR. 1910 † 22.09.1939 CZEŚNIKI, KPR. WRONA STANISŁAW † 22.09.1939 TOPORNICA, KPT. FETELA ANTONI † 22.09.1939 POD TOMASZOWEM LUB[ELSKIM].

\section{LISTA POLEGŁYCH ŻOŁNIERZY KONSPIRACJI ZBROJNEJ}

\section{TABLICE ZBIOROWE}

STRZ. PUCHACZ Z KRYNIC, STRZ. BAŁABUCH STANISŁAW [PSEUDONIM] „STASZKO” Z KOMAROWA, STRZ. NAWROCKI STANISŁAW „STRZEPIOREK” Z KSIĘŻOSTAN, STRZ. SZMULC JAN „PIONIER” Z POLANÓWKI, STRZ. JASTRZĘBSKI JAN „ZAWAŁA” Z ŁABUŃ, STRZ. GUTOWSKI ZYGMUNT „WILGA” Z TOMASZOWA LUBELSKIEGO, STRZ. NN „WOŁYNIAK”

CHOR. SZARY „SĘP” Z KRYNIC, CHOR. CHEĆKO JAN, KPR. KURZĘPA HIPOLIT „SĘP” Z KRZYWEGO STOKU, ST. STRZ. MILLER BOGDAN „TWARDY” Z KSIĘŻOSTAN, STRZ. CZARNECKI IRENEUSZ Z KRYNIC, STRZ. DZYGAŁO JÓZEF Z KRYNIC, STRZ. NOWICKI JERZY Z KRYNIC

${ }^{66}$ Nazwisko niedokończone. 


\section{TABLICE INDYWIDUALNE}

ALBINGIER MICHAŁ s. PIOTRA † 01.04.1944 ROTUNDA, ALBINGIER MIECZYSŁAW s. MICHAŁA † 01.04.1944 ROTUNDA, BARAN CZESŁAW OSICZYNA † 01.04.1944, STRZ. BASISTA ADAM UR. 1912 † 18.09.1939 PAARY, BIAŁÓWNA HALINA ZAMOŚĆ, STRZ. BŁASZCZYK ANTONI † 29.09.1939, BORZYM BOLESŁAW s. STEFANA UR. 29.09.1897 † 19.09.1939 ZIELONE, BUCZEK ANTONI s. ANTONIEGO ZAMOŚĆ † 23.09.1939, CIEŚLA MIECZYSŁAW † 1944 ROTUNDA, CIOCH CZESŁAW † 09.04.1944, CHOMICKI MIECZYSŁAW † 24.07.1944, STRZ. DROZD STANISŁAW † 20.09.1939 MAJDAN GÓRNY, DZIK WACŁAW, FEDAK MICHAŁ, FEDAK PIOTR, BOGDAN JULIAN FENC PS[EUDONIM] „WIR” UR. 07.08.1924 † 25.02.1944, FURMANIAK JAN † 01.04.1944, GONTARZ JAN † 01.04.1944, ks. GOMUŁKA ANTONI, GRYGIEL JAN, HOROŚ MICHAŁ, JABŁOŃSKI JAN, JABŁOŃSKI JAN EDWARD, JACHYMEK HENRYK UR. 24.08.1925 PSEUD[ONIM] „DZIURDZIK, JELEŃ” † 20.07.1944 ROTUNDA, JACHYMEK JAN UR. 07.10.1919 PS. „SZCZUREK” † 20.07.1944 ROTUNDA, JASINA JÓZEF ŻYŁ L[AT] 20 † 01.04.1944 ROTUNDA, JASINA STEFAN ŻYŁ L. 24 † 1.04.1944 ROTUNDA, JURKIEWICZ BOLESŁAW ŻYŁ L. 21 † 20.07.1944, KLIMKO CZESŁAW † 01.04.1944 ROTUNDA, KOPEĆ TOMASZ, KORZENIOWSKI ZYGMUNT † 01.04.1944, KOWALCZYK KAZIMIERZ ŻYŁ LAT 44 ZAMORDOWANY NA ROTUNDZIE, KUBIK ROMAN, KUREK ANDRZEJ, KURZEMPA CZESŁAW † 01.04.1944, KURZEMPA ANDRZEJ † 01.04.1944, KUPICZ GRZEGORZ † 01.04.1944, KUPICZ MICHAŁ, KUPICZ ŁUKASZ † 01.04.1944, LECHMAN JAN, ŁUSZCZAK JAN, MALINOWSKI WŁADYSŁAW, MALISZEWSKI EDWARD, MATYSIAK JÓZEF ŻYŁ L. 43 † ROTUNDA, NIEDOBIT WACŁAW † 01.04.1944, NIEDZIELSKI JAN s. STANISŁAWA ŻYŁ L. 26 † 20.07.1944, NIEDŹWIEDŹ JÓZEF † 01.04.1944, MJR NIEMIEC WŁADYSŁAW UR. 23.04.1897 † 23.09.1939, ONYSZKIEWICZ JERZY, PALUCH STANISŁAW, PASIECZNY WŁADYSŁAW † 01.04.1944, PIŁAT HIPOLIT † 1.04.1944, PIÓRO JAN † 01.04.1944, PIÓRO PIOTR † 01.04.1944, PITAK ANTONI † 01.04.1944 ROTUNDA, PITAK ROMAN † 01.04.1944 ROTUNDA, PLIŻGA WŁADYSŁAW PS. „ORLIK” † 20.07.1944 ROTUNDA, PODCZASKA WERONIKA † 11.07.1944 ROTUNDA, POMYKAŁA JÓZEF † 01.04.1944, POPOWICZ JÓZEF, RABIEGA TOMASZ † 24.07.1944, RÓJ JÓZEF, SCHAB STANISŁAW † 01.04.1944, SACHAJKO PAWEŁ † 01.04.1944, SKOTARSKI CZESŁAW † 02.1944 ROTUNDA, STELMASZCZUK IGNACY TYSZOWCE ŻYŁ L. 40 † 20.07.1044, STELMASZCZUK WŁADYSŁAW, STELMASZCZUK KAZIMIERZ, SZALA JAN † 01.04.1944 ROTUNDA, SZALA WŁADYSŁAW † 01.04.1944 ROTUNDA, SZYNKARUK JAN † 20.07.1944, ŚMIECIUCH JÓZEF, TRZEŚNIOWSKI ALEKSANDER † 01.04.1944, TYBULCZUK FRANCISZEK PS. „TYGRYS” UR. 14.08.1905 † 20.07.1944 ROTUNDA, WĘCŁAWIK STANISŁAW, PPOR WICIEJEWSKI JAN PS. „WICZ” UR. 08.01.1901 + 20.07.1944, WOŁOSZYN STANISŁAW ŻYŁ L. 25 † 20.07.1944, WORONOWICZ TOMASZ † 1.04.1944, WÓJCIK JAN, SZYPUŁA MICHAŁ ŻYŁ L. 34, GONTARZ WITOLD, GONTARZ STEFAN, OŻGA ADAM, PŁATEK WINCENTY, ŚLEDŹ JAN, ŁENYK WŁADYSŁAW, SAPUTA JAN, KOŁOWSKI FRANCISZEK, KOZŁOWSKI, KŁOS JAN, SUROWIEC KAZIMIERZ, KAŁUŻNIAK PIOTR, WODYK JAN, KOPEĆ TOMASZ, GUŁOWSKI CZESŁAW, MIEŻYŃSKI ZBIGNIEW, SANCEWICZ BRONISŁAW, PIROGOWICZ JAN, PIROGOWICZ WŁADYSŁAW, PIROGOWICZ BOLESŁAW, CISEK CZESŁAW, ZARĘBSKI JÓZEF, ŁOCHYŃ ALEKSANDER, KAZAŃSKI JÓZEF, SOBIESZCZAŃSKI ZBIGNIEW, KOZŁOWSKI STANISŁAW, SKUBISZEW- 
SKI JÓZEF, FRANKIEWICZ MAR... ${ }^{67}$ NISKO, ŚMIECIUCH JÓZEF, RAK TADEUSZ UR. 27.10.1921 † 20.07.1944 ROTUNDA, WRONOWICZ TOMASZ † 01.04.1944, BODYS CZESŁAW † 01.04.1944, PORTUS STANISŁAW ŻYŁ L. 27 † 01.04.1944, WNUK PIOTR, NAZAR JAN, GÓRYŃSKI JAN, KOSTRO-SZCZAWIŃSKI WACŁAW ŻYŁ L. 21 † 04.02.1943, SITARZ JAN PS. „ZEMSTA” ŻYŁ L. 19 † 04.02.1943, PACHLA WACŁAWA LAT 24 † 04.02.1943, PRUS WITOLD PS. „WIESŁAW” † 04.02.1943, ŻOŁNACZ BRONISŁAW ŻYŁ L. 21 † 04.02.1943, MYSZAK KAZIMIERZ PS. „BARCZESKI” ŻYŁ L. 35 † 04.02.1943, PIRÓG WŁADYSŁAW PS. „SZCZYGIEŁ” LAT 21 † 04.02.1943, ŚMIECIUSZEWSKI WŁADYSŁAW PS. „KOZAK” † 04.02.1943, KICIŃSKI JAN EDWARD † 04.02.1943, WĘCŁAWIK WACŁAW PS. „BOA” ŻYŁ L. 22 † 04.02.1943, KICIŃSKI TADEUSZ ŻYŁ L. 21 † 04.02.1943, SUWAŁA JÓZEF STANISŁAW PS. „SĘP” ŻYŁ L. 22 † 04.02.1943, SURMACZ WŁADYSŁAW PS. „DENKOWSKI” ŻYŁ L. 18 † 04.02.1943, NAKLICKI WIKTOR PS. „KORTEZ” ŻYŁ L. 22 † 04.02.1943, MARZEC ADAM PS. „ZEZULA” ŻYŁ L. 22 † 04.02.1943, KUSY STANISŁAW ŻYŁ L. 23 † 04.02.1943, GRUDZIEŃ PIOTR PS. „KLERYK” ŻYŁ LAT 23 † 04.02.1943, BŁASZCZAK EDWARD ŻYŁ L. 25 † 04.02.1943, GRZESIUK BOLESŁAW PS. „OLCHOWSKI” ŻYŁ L. 26 † 04.02.1943, SZADY TADEUSZ PS. „STRZELECKI” ŻYŁ L. 20 † 04.02.1943, CISŁO ANTONI PS. „LIS” ŻYŁ L. 20 † 04.02.1943, PITAK ANTONI

OGN. BOCHEŃSKI JÓZEF UR. 1905 † 14.09.1943 HRUBIESZÓW, CZESŁAW JUNIK UR. $1924+1944$

PPOR. LUTY WŁADYSŁAW s. FRANCISZKA UR. 1894 † 21.09.1939, STRZ. BEDNARCZYK † 20.09.1939, ROŻNIAKOWSKI TADEUSZ † 21.09.1939, ST. STRZ. MAŁECKI WŁADYSŁAW UR. 06.05.1914 † 18.09.1939, STRZ. MATESZKO † 18.09.1939, STRZ. MAZIOŁ LUDWIK † 18.09.1939, STRZ. MARZEC JAN † 20.09.1939, STRZ. MANKIER KAROL † 18.09.1939, PLUT. MALIK † 19.09.1939, SZONERT ALFRED † 1939

\section{Abstract}

\section{Rotunda - the First Commemorated Memorial of Martyrdom in the Zamojszczyzna Region}

The Rotunda was a military object in the defense system of Zamosc Fortress in the $19^{\text {th }}$ century. During World War II, it served as a prisoner of war transit camp for the German Security Police. Between 1940 and 1944 many representatives of the local elites as well as underground members died there. The estimated number of victims is around 8000 . The total number of prisoners that were moved through the transit camp is estimated to be around 50 000. Rotunda was the first site in the region to be commemorated after the war. The initiative to commemorate the place was a result of social activity. Despite many difficulties, the Rotunda and the adjacent land were secured. In the 1950s, a lot of bodies of the World War II victims were exhumed into the Rotunda. Currently, it is a very important symbol

${ }_{67}$ Zapis imienia niepełny. 
of martyrdom in the Zamojszczyzna region. Among the buried are: Polish soldiers who died in September 1939, partisans, Jewish and Romani populace, as well as Soviet soldiers.

\section{Keywords:}

World War II, martyrdom, memorial, Zamojszczyzna. 